\begin{tabular}{|c|c|c|c|c|c|c|c|c|}
\hline \multicolumn{3}{|c|}{$\begin{array}{l}\text { 2. To: (Receiving Organization) } \\
\text { Distribution }\end{array}$} & \multicolumn{2}{|c|}{$\begin{array}{l}\text { 3. From: (Originating Organization) } \\
\text { Nuclear Safety }\end{array}$} & \multicolumn{4}{|c|}{$\begin{array}{l}\text { 4. Related EDT No.: } \\
\qquad \text { N/A }\end{array}$} \\
\hline \multicolumn{3}{|c|}{$\begin{array}{l}\text { 5. Proj/Prog./Dept/Div.; } \\
\text { Spent Nuclear Fuel }\end{array}$} & \multicolumn{2}{|c|}{$\begin{array}{l}\text { 6. Design Authority/ Design Agent/Cog. Engr.: } \\
\text { T. B. Powers, R3-26, 372-2509 }\end{array}$} & \multicolumn{4}{|c|}{$\begin{array}{r}\text { 7. Purchase Order No.: } \\
\text { N/A }\end{array}$} \\
\hline \multicolumn{5}{|c|}{ 8. Originator Remarks: } & \multicolumn{4}{|c|}{$\begin{array}{r}\text { 9. Equip./Component No.: } \\
\text { N/A }\end{array}$} \\
\hline \multicolumn{5}{|c|}{ For approval and release. } & \multicolumn{4}{|c|}{$\begin{array}{r}\text { 10. System/Bldg./Facility: } \\
\text { N/A }\end{array}$} \\
\hline \multirow{3}{*}{\multicolumn{2}{|c|}{ 11. Receiver Remarks: }} & \multirow{3}{*}{\multicolumn{3}{|c|}{ 11A. Design Baseline Document? [] Yes [x] No }} & \multicolumn{4}{|c|}{$\begin{array}{r}\text { 12. Major Assm. Dwg. No.: } \\
\text { N/A }\end{array}$} \\
\hline & & & & & \multicolumn{4}{|c|}{$\begin{array}{l}\text { 13. Permit/Permit Application No.: } \\
\text { N/A }\end{array}$} \\
\hline & & & & & \multicolumn{4}{|c|}{$\begin{array}{l}\text { 14. Required Response Date: } \\
\text { N/A }\end{array}$} \\
\hline 15. & & DAT & [RANSMI & & (F) & (G) & (H) & (I) \\
\hline $\begin{array}{l}\text { (A) } \\
\text { ltem } \\
\text { No. }\end{array}$ & (B) Document Drawing No. & $\begin{array}{l}\text { (C) } \\
\text { Sheet } \\
\text { No. }\end{array}$ & $\begin{array}{l}\text { (D) } \\
\text { Rev. } \\
\text { No. }\end{array}$ & (E) Tite or Description of Datis Tensmittod & $\begin{array}{l}\text { Approval } \\
\text { Designator }\end{array}$ & $\begin{array}{c}\text { Reason } \\
\text { for Trans- } \\
\text { mittal }\end{array}$ & $\begin{array}{l}\text { Oripi- } \\
\text { nator } \\
\text { Dispo- } \\
\text { sition } \\
\end{array}$ & $\begin{array}{c}\text { Recciver } \\
\text { Disposition }\end{array}$ \\
\hline 1 & SNF-5413 & N/A & 0 & $\begin{array}{l}\text { Probability of Potential Multi- } \\
\text { Canister Overpack Cask Drop } \\
\text { in the K West Basin South } \\
\text { Loadout Pit }\end{array}$ & $S^{n}$ & 1,2 & 1 & 1 \\
\hline & & & & & & & & \\
\hline & & & & & & & & \\
\hline & & & & & & & & \\
\hline & & & & & & & & \\
\hline & & & & & & & & \\
\hline
\end{tabular}

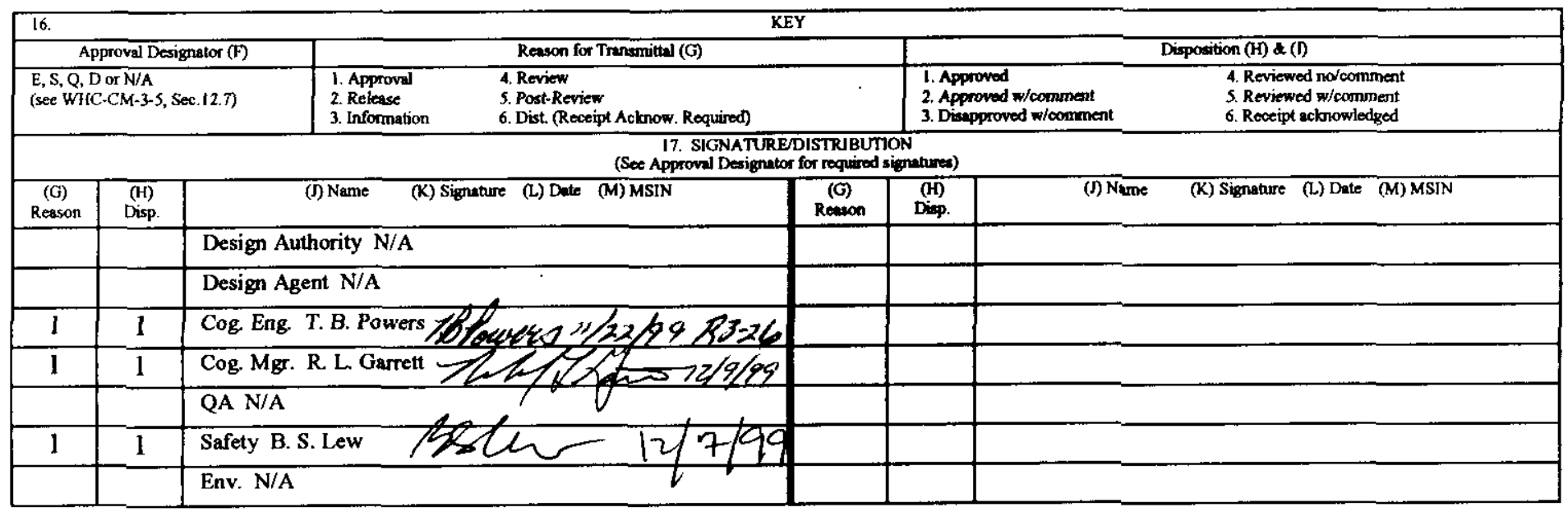
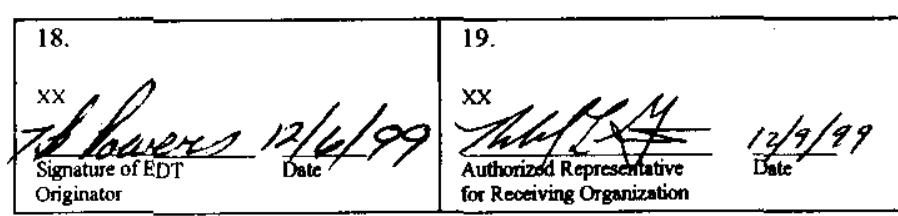

21. DOE APPROVAL (if required)

Ctrl. No.

[ ] Approved

[] Approved w/comments

[] Disapproved w/comments

BD-7400-172-2 (05/96) GEF097 


\section{Potential Multi-Canister Overpack Cask Drop in the K West Basin South Loadout Pit}

\section{T. B. Powers}

Fluor Daniel Hanford, Inc., Richland, WA 99352

U.S. Department of Energy Contract DE-AC06-96RL13200

EDT: 626899

Org Code: 2F200

B\&R Code: EW31354040
UC: 620

Charge Code: $105530 / \mathrm{CB80}$

Total Pages: 27

Key Words: Spent nuclear fuel, multi-canister overpack (MCO), N Reactor fuel, probability, K Basin

Abstract: This calculation note documents the probabilistic calculation of a potential drop of a multicanister overpack (MCO) cask or MCO cask and immersion pail at the $\mathrm{K}$ West Basin south loadout pit. The calculations are in support of the cask loading system (CLS) subproject alignment of CLS equipment in the $\mathrm{K}$ West Basin south loadout pit.

TRADEMARK DISCLAIMER. Reference herein to any specific commercial product, process, or service by trade name, trademark, manufacturer, or otherwise, does not necessarily constitute or imply its endorsement, recommendation, or favoring by the United States Government or any agency thereof or its contractors or subcontractors.

Printed in the United States of America. To obtain copies of this document, contact: Document Control Services, P.O. Box 950, Mailstop H6-08, Richiand WA 99352, Phone (509) 372-2420; Fax (509) 376-4989.
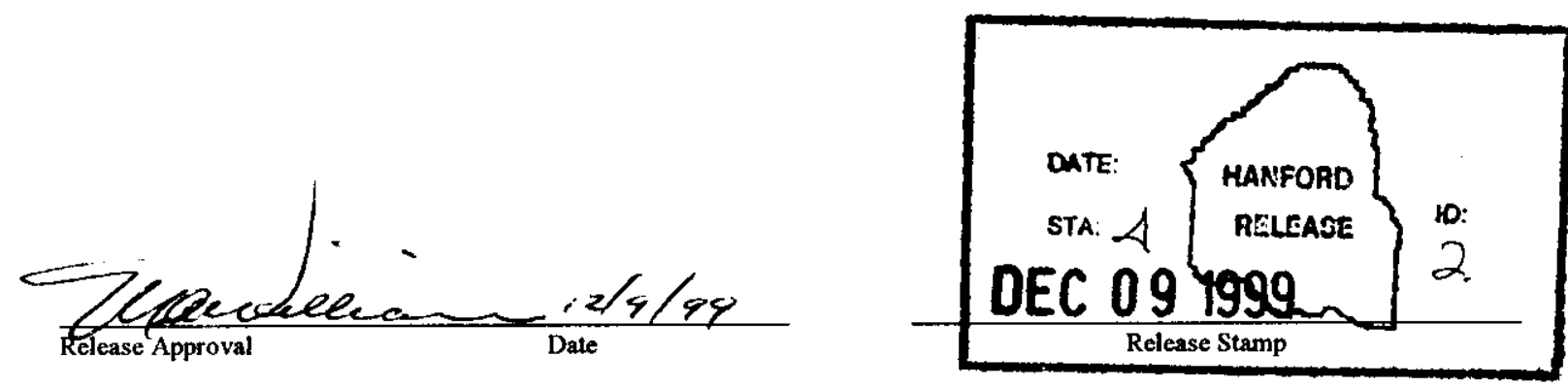

\section{Approved for Public Release}




\section{POTENTIAL MULTI-CANISTER OVERPACK CASK DROP IN THE K WEST BASIN SOUTH LOADOUT PIT}

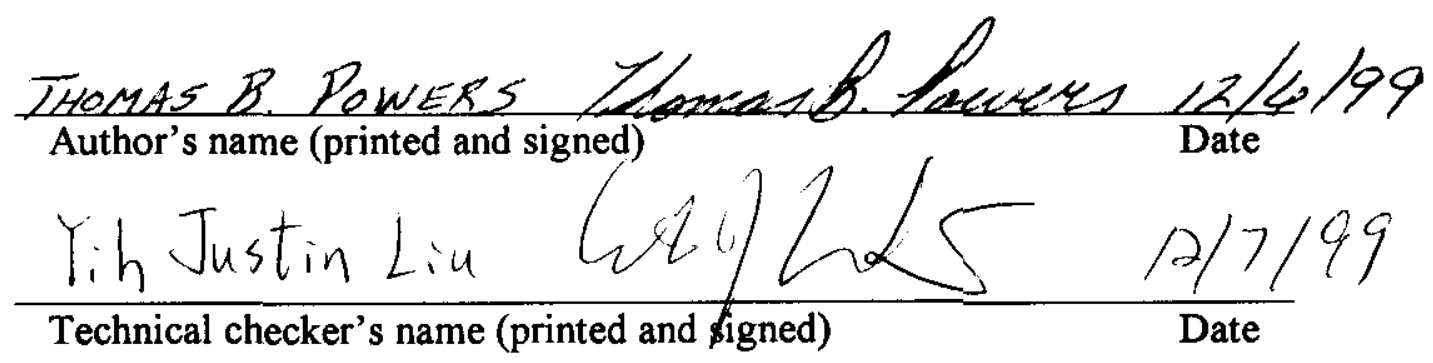


SNF-5413 REV 0

This page intentionally left blank. 


\section{POTENTIAL MULTI-CANISTER OVERPACK CASK DROP IN THE K WEST BASIN SOUTH LOADOUT PIT}

\section{PURPOSE AND OBJECTIVES}

The purpose of this calculation note is to document the probabilistic calculation of a potential drop of a multi-canister overpack (MCO) cask or MCO cask and immersion pail on a per lift basis at the $\mathrm{K}$ West Basin south loadout pit. The Cask Loading System (CLS) subproject needs to align CLS equipment in the K West Basin south loadout pit. To perform this equipment alignment, an MCO cask or an MCO cask mockup needs to be used for four different lifts. The use of an existing MCO cask is desired because of availability. A probabilistic calculation of the potential for a drop will be used as part of the basis for seeking U.S. Department of Energy approval to use an MCO cask for the four lifts required for CLS equipment alignment.

With some minor changes, the probabilistic calculation for the CLS equipment alignment also can be used to complete a frequency calculation for operations at the $\mathrm{K}$ West Basin south loadout pit over 2 to 3 years. The recalculation raises the final drop probability per lift from $1.5 \times 10^{-5} /$ lift to $1.75 \times 10^{-5} / \mathrm{lift}$, which is not a significant change. This recalculated probability can be used to calculate frequencies to support the analysis of design basis accidents presented in the K Basins Final Safety Analysis Report.

\section{SUMMARY OF FINAL RESULTS AND CONCLUSIONS}

The point estimate value calculated for the probability of potential drop per lift in the south loadout pit is $1.5 \times 10^{-5} / \mathrm{lift}$. The probability of $1.5 \times 10^{-5} / \mathrm{lift}$ is about a factor of 2 times smaller than the midpoint of the crane load drop failure data provided in NUREG-0612, Control of Heavy Loads at Nuclear Power Plants. The point estimate value for the frequency of potential drops in the south loadout pit is $7.05 \times 10^{-3} / \mathrm{yr}$.

\section{METHODOLOGY}

Fault tree analysis is used to calculate the probability of a potential MCO cask drop in the $\mathrm{K}$ West Basin south loadout pit. The fault tree logic represents the failures required before a potential drop by the transfer bay crane could occur in the K West Basin south loadout pit.

\section{ASSUMPTIONS}

The following assumptions are represented by the fault tree logic and failure probabilities developed for this calculation note.

1. The basic human error probability (BHEP) used in the fault tree to represent an operator error is 0.03 . This value is documented in NUREG/CR-4772, Accident 
Sequence Evaluation Program Human Reliability Analysis Procedure (step 6 in Table 4-1, page 4-3).

2. It is assumed that the controller that manages the load cell signals for overload protection can fail such that no overload signal is sent to the $110 \%$ alarm or no overload signal is sent to shut off power to hoisting at $125 \%$ of normal load.

3. It is assumed that a single failure of an MCO cask lifting attachment or a crane hook or a crane cable will result in a drop of the MCO cask.

4. It is assumed that three of the four rigging lines (each comprising an upper hook, sling, and lower hook) on the immersion pail would have to fail to allow an immersion pail to drop.

5. For crane bridge failure, material defect, damage, and/or fatigue is assumed to be a probability of $1.0 \times 10^{-7}$.

6. For crane trolley failure, material defect, damage, and/or fatigue is assumed to be a probability of $1.0 \times 10^{-7}$.

7. Loss of electrical power failure is based on Hanford Site specific loss of power data of 1.22/yr (WHC-EP-0811).

8. The limit switches and brakes are assumed to be tested before each lift for the CLS cask alignment activity. The limit switches and brakes are assumed to be tested every year for normal operations.

\section{INPUT DATA}

The following paragraphs describe the failure data used in the fault tree logic that is described in the section entitled "Calculations" and presented graphically in Figure 1.

Event KWOP1 is the operator error that leads to "two-blocking" the transfer bay crane with a load attached. As mentioned in the assumptions above, the BHEP used for this operator error is 0.03 .

Event KWLSW1 is the failure of the first limit switch to stop transfer bay crane hoisting to prevent two-blocking. Since the limit switches are assumed to be tested before each lift performed for CLS alignment, the failure of these limit switches over time will be detected before a lift is performed. Thus the dominant failure mode of the limit switch is a failure to open or close on demand. The probability of a limit switch failing to open or close on demand is $3.0 \times 10^{-5} /$ demand based on EGG.SSRE-8875, Generic Component Failure Data Base for Light Water and Liquid Sodium Reactor PRAs (page 22). For normal operations, the limit switches as assumed to be tested once a year, and thus the failure of these limit switches over time will dominate the failure to open or close on demand. The probability of a limit switch failing over time is $1 \times 10^{-6} / \mathrm{h}$ (EGG-SSRE-8875, page 22). Conservatively assuming 10,000 hours per year, the failure probability of the limit switches is $\left(1 \times 10^{-6} / \mathrm{h}\right)(10,000$ hours $)=1 \times 10^{-2}$. 
Event KWLSW2 is the failure of the second or "high" limit switch to stop transfer bay crane hoisting to prevent two-blocking. The discussion for KWLSW1 above applies to KWLSW2. Thus the dominant failure probability for KWLSW2 is $3.0 \times 10^{-5} /$ demand for CLS alignment. The dominant failure probability for KWLSW2 for ongoing operations is $1 \times 10^{-2}$.

Event KWOP2 is the operator error that leads to "load hang-up" of the transfer bay crane with a load attached. As mentioned in the assumptions above, the BHEP used for this operator error is 0.03 .

Event KWLCA is the random failure of the $110 \%$ overload alarm given a load hang-up has occurred. Alarms randomly fail about $1.0 \times 10^{-6} / \mathrm{h}$ (EGG-SSRE-8875, page 21). Conservatively assuming $10,000 \mathrm{~h} / \mathrm{yr}$, a mission time over which the alarm could fail is 10,000 hours; thus the alarm would fail $\left(1.0 \times 10^{-6} / \mathrm{h}\right)(10,000 \mathrm{~h})=1.0 \times 10^{-2}$. Thus the probability that the alarm will not function given a load hang-up that produces a $110 \%$ overload is calculated to be about $1.0 \times 10^{-2}$. This assumes that once a year the $110 \%$ overload circuit and alarm are tested to verify the alarm works as desired.

Event KWOP3 is the operator error of failing to stop hoisting once the $110 \%$ overload alarm has sounded given a load hang-up of the transfer bay crane with a load attached. As mentioned in the assumptions above, the BHEP used for this operator error is 0.03 .

Event KWLCPOW is the random failure of the overload protection controller to send a signal to stop hoisting given a $125 \%$ overload. A controller failure is assumed to be equivalent to microcircuit failure (INSPEC, page 92), which has a failure rate of about $1.0 \times 10^{-8} / \mathrm{h}$. Conservatively assuming $10,000 \mathrm{~h} / \mathrm{yr}$, a mission time over which the alarm could fail is 10,000 hours; thus the controller would fail $\left(1.0 \times 10^{-8} / \mathrm{h}\right)(10,000 \mathrm{~h})=1.0 \times 10^{-4}$. Thus the probability of the controller failing to send a signal when there is a $125 \%$ overload is calculated to be $1.0 \times 10^{-4}$. This assumes that once a year the $125 \%$ overload circuit in the controller is tested to verify the $125 \%$ overload shutdown signal works as desired.

Event KWOP4MIS is the operator error of incorrectly resetting both load cell set points so they trip at higher loads than desired for the $110 \%$ and $125 \%$ overload protection. This operator error would thus fail both the $110 \%$ overload alarm and the $125 \%$ overload power shutdown. As mentioned in the assumptions above, the BHEP used for this operator error is 0.03 . The BHEP is multiplied by an additional 0.01 to take credit for procedural steps that require a work package be developed to reset the load cell set points and a requirement to get a key from the shift manager for access to the controller to execute the work package. Thus the probability of event KWOP4MIS is $3.0 \times 10^{-4}$.

Events KWCLA, KWCRH, KWCCA, and KWCDR are failures of the cask lifting attachment, crane hook, crane cable, and crane drum, respectively. These are mechanical component failures. Navy crane failure data from NUREG-0612 indicate a low end failure probability per lift of $2.5 \times 10^{-5} /$ lift (NUREG-0612, page 4-3). NUREG-0612 also indicates that about $17 \%$ of the drops are related to crane component failures based on the Navy data (NUREG-0612, page 4-4). Thus $\left(2.5 \times 10^{-5} / \mathrm{lift}\right)(0.17)=4.3 \times 10^{-6} /$ lift. Given that there are 
four components that could lead to the drop, the probability of each one failing could be considered to be about one-fourth of the value $4.3 \times 10^{-6} / \mathrm{lift}$, or about $1.0 \times 10^{-6} / \mathrm{lift}$.

Events KWLB, KWLS1UH, KWLS1S, KWLS1LH, KWLS2UH, KWLS2S, KWLS2LH, KWLS3UH, KWLS3S, KWLS3LH, KWLS4UH, KWLS4S, and KWLS4LH are failures of the immersion pail lift beam, upper hook, lifting sling, and lower hook of each of the four lifting rigging lines, respectively. Similar logic was used for the failure probability of each of these components as was used for events KWCLA, KWCRH, KWCCA, and KWCDR in the previous paragraph. Since there are more than four components, the failure probability per component would be less than $1.0 \times 10^{-6} /$ ift per component but for simplicity and conservatism $1.0 \times 10^{-6} / \mathrm{lift}$ is assigned to each of the these component failure probabilities.

Event KWHG is a failure of the drum hoist gear. Failure data on gear failures in a Savannah River failure data compilation (DP-1633, page 17 ) range from $5.0 \times 10^{-8} / \mathrm{h}$ to $1.0 \times 10^{-5} / \mathrm{h}$. For conservatism, $1.0 \times 10^{-5} / \mathrm{h}$ is chosen as the failure rate for drum hoist gear failure. Assuming a 1-hour lift, the failure probability is $1.0 \times 10^{-5}$.

Event KWDISSEN is a failure of a discontinuity sensor associated with the hoist drum gears such that a signal is not sent to the programmable logic controller and then on to the drum brake to apply the drum brake. Failure data for sensors indicate $1.0 \times 10^{-6}$ failures $/ \mathrm{h}$ (EGG-SSRE-8875, page 23). Conservatively assuming $10,000 \mathrm{~h} / \mathrm{yr}$, a mission time over which the alarm could fail is 10,000 hours; thus the sensor would fail with a probability of $\left(1.0 \times 10^{-6} / \mathrm{h}\right)$ $(10,000 \mathrm{~h})=1.0 \times 10^{-2}$.

Event KWSHB is a failure of a solenoid hoist brake to operate on demand. The failure probability for a solenoid hoist brake is assumed to be represented by the failure probability of a solenoid valve to open on demand, which is $1.0 \times 10^{-3} /$ demand (DP-1633, page 38).

Event KWRG is a failure of a reducer gear. Failure data on gear failures in a Savannah River failure data compilation (DP-1633, page 17) range from $5.0 \times 10^{-8} / \mathrm{h}$ to $1.0 \times 10^{-5} / \mathrm{h}$. For conservatism, $1.0 \times 10^{-5} / \mathrm{h}$ is chosen as the failure rate for reducer gear failure. Assuming a 1 -hour lift, the failure probability is $1.0 \times 10^{-5}$.

Event KWMLB is a failure of a mechanical load brake to operate on demand. Brake failure data from the Savannah River failure data compilation (DP-1633, page 11) range from $4.0 \times 10^{-6} / \mathrm{h}$ to $1.0 \times 10^{-5} / \mathrm{h}$. Conservatively assuming $10,000 \mathrm{~h} / \mathrm{yr}$, a mission time over which the alarm could fail is 10,000 hours; thus the brakes would fail with an upper probability of $\left(1.0 \times 10^{-5} / \mathrm{h}\right)(10,000 \mathrm{~h})=1.0 \times 10^{-1}$. Assuming the brakes were applied 100 times per year, the demand failure would be $1.0 \times 10^{-1} / 100$ demands $=1.0 \times 10^{-3} /$ demand. This value compares well with the solenoid brake failure probability on demand, so $1.0 \times 10^{-3}$ is used to represent the failure probability of the mechanical load brake per demand.

Event LOEP is a loss of electrical power as represented by losses of power in the 200 Area over a 20-year period. Based on WHC-EP-0811, Analysis of Power Loss Data for the 200 Area Tank Farms in Support of K Basin SAR Work, a loss of electrical power occurs about $1.22 / \mathrm{yr}$ in the 200 Areas. This can be judged to be representative of power losses in the 
$100 \mathrm{~K}$ Area because the Hanford Site grid supplies all areas on the Hanford Site. The yearly average power loss can be represented as an hourly power loss of $1.4 \times 10^{-4} / \mathrm{h}$. Thus for a 1-hour operation period per lift, the probability of loss of power per lift is $1.4 \times 10^{-4}$.

Event KWEM is the electric hoist motor fails to continue running. Based on failure data for motor-driven pumps failing to run (EGG-SSRE-8875), the failure rate applied to an electric motor failing to run is $3.0 \times 10^{-5} / \mathrm{h}$. Thus for a 1 -hour operation period per lift, the probability of electric hoist motor failing to run is $3.0 \times 10^{-5}$.

\section{CALCULATIONS}

The logic to calculate the probability of a drop per lift is modeled as a fault tree in Figure 1. The solution of the fault tree in Figure 1 yields a list of minimal cutsets based on Boolean logic. A minimal cutset is the minimum number of failure events that will result in the top event. The failure probabilities discussed in the input data section above were used to quantify the solution of the fault tree in Figure 1. The computer software code CAFTA, version 2.1, was used to yield the minimal cutsets and quantify the top event of the fault tree in Figure 1. CAFTA, version 2.1, has been validated as reported in WHC-SD-MP-SWD-0004, CAFTA Computer Program Testing and Acceptance Report, and the results generated for this calculation note have been randomly spot checked by the technical reviewer to ensure the calculations were performed correctly. Table 1 is a listing of the minimal cutsets and their quantification for logic in Figure 1 using the input data discussed above.

An example quantification calculation of the following set of failures (cutset) that lead to a load drop due to a hang-up scenario involves the multiplication of the probabilities for events KWLCA, KWLCPLC, and KWOP2. This is cutset number 13 in Table 1:

$$
\left(1.0 \times 10^{-2}[\mathrm{KWLCA}]\right)\left(1.0 \times 10^{-4}[\mathrm{KWLCPOW}]\right)(0.03[\mathrm{KWOP} 2])=3.0 \times 10^{-8} \text {. }
$$

To calculate the frequency of MCO cask drops in the south loadout pit during normal operations, the probability of a drop per lift is multiplied by the expected number of lifts per year. For the frequency of MCO drops in the south loadout pit caused by a seismic event, the frequency calculated for drops during normal operations is added to the frequency of the design basis seismic event multiplied by a conservative fraction of a year that MCO casks are being lifted over the south loadout pit.

\section{RESULTS}

Solving the logic in the fault tree in Figure 1 results in a listing of 124 minimal cutsets, as listed in Table 1. The quantification of the minimal cutsets resulting from solving the logic in the fault tree in Figure 1 is also represented by the numbers on the far right hand side of Table 1 for each minimal cutset. The total probability of a potential load drop per lift is $1.45 \times 10^{-5}$, which is shown in the upper right hand corner of Table 1 under the column heading "MOD./CS. PROB.". This number represents a point estimate value for the probability of potential drop per lift in the south loadout pit $\left(1.5 \times 10^{-5} /\right.$ lift $)$ during CLS alignment. 
In representing normal operations, minimal cutset number 16 would change because the probability of limit switches failing during normal operations is different than the probability of their failing during CLS alignment. For normal operations, minimal cutset number 16 (KWLSW1, KWLSW2, and KWOP1) has a probability of $\left(1 \times 10^{-2}\right)\left(1 \times 10^{-2}\right)(0.03)=3 \times 10^{-6}$. Thus the point estimate value for the probability of a potential drop per lift in the south loadout pit for normal operations would be $1.75 \times 10^{-5} /$ lift. Assuming 400 lifts per year, the frequency of drops caused by crane failures (other than those involving seismic events) is $\left(1.75 \times 10^{-5} /\right.$ ift) ( $400 \mathrm{lifts} / \mathrm{yr})=7 \times 10^{-3} / \mathrm{yr}$. The frequency of a design basis seismic event is $4 \times 10^{-4} / \mathrm{yr}$ at the $\mathrm{K}$ Basins. It is conservatively assumed that MCO casks will be lifted over the south loadout pit 1,000 hours in a year (a normal lift is probably less than 1 hour per lift). Thus the frequency at which an MCO cask is vulnerable to a drop over the south loadout pit because of a design basis seismic event is $\left(4 \times 10^{-4} / \mathrm{yr}\right)[(1,000 \mathrm{~h}) /(8,760 \mathrm{~h})]=4.6 \times 10^{-5} / \mathrm{yr}$. Thus the total frequency of drops is the sum of $7 \times 10^{-3} / \mathrm{yr}$ and $4.6 \times 10^{-5} / \mathrm{yr}$ or $7.046 \times 10^{-3} / \mathrm{yr}$.

\section{CONCLUSIONS}

The probability of $1.5 \times 10^{-5} /$ lift is about a factor of 2 times smaller than the value used in WHC-SD-WM-SAR-062, $K$ Basins Final Safety Evaluation Report (page 3A-3), for cask-MCO drops $\left(2.7 \times 10^{-5} / \mathrm{lift}\right)$. The value of $2.7 \times 10^{-5} / \mathrm{lift}$ is the midpoint of the frequency range for crane load drops described in NUREG-0612. The upper end of the frequency range for crane load drops described in NUREG-0612 is $3.0 \times 10^{-4} / \mathrm{lift}$.

\section{REFERENCES}

DP-1633, 1982, Component Failure-Rate Data with Potential Applicability to a Nuclear Fuel Reprocessing Plant, E.I. du Pont de Nemours \& Co., Savannah River Laboratory, Aiken, South Carolina.

EGG-SSRE-8875, 1990, Generic Component Failure Data Base for Light Water and Liquid Sodium Reactor PRAs, EG\&G Idaho, Incorporated, Idaho Falls, Idaho.

INSPEC (Institution of Electrical Engineers), 1981, Electronic Reliability Data, a Guide to Selected Components, Unwin Brothers Limited, The Gresham Press, Old Woking, Surrey, England.

NUREG-0612, 1980, Control of Heavy Loads at Nuclear Power Plants, U.S. Nuclear Regulatory Commission, Washington, D.C.

NUREG/CR-4772, 1987, Accident Sequence Evaluation Program Human Reliability Analysis Procedure, Sandia National Laboratories, Albuquerque, New Mexico.

WHC-EP-0811, 1994, Analysis of Power Loss Data for the 200 Area Tank Farms in Support of $K$ Basin SAR Work, Westinghouse Hanford Company, Richland, Washington. 


\section{SNF-5413 REV 0}

WHC-SD-MP-SWD-0004, 1993, CAFTA Computer Program Testing and Acceptance Report, Rev. 0-D, Westinghouse Hanford Company, Richland, Washington.

WHC-SD-WM-SAR-062, 1999, K Basins Final Safety Analysis Report, Rev. 3L, Westinghouse Hanford Company, Richland, Washington. 


\section{SNF-5413 REV 0}

Figure 1. Multi-Canister Overpack Cask Drop in K West South Loadout Pit during Cask Loading System Alignment. (sheet 1 of 8)

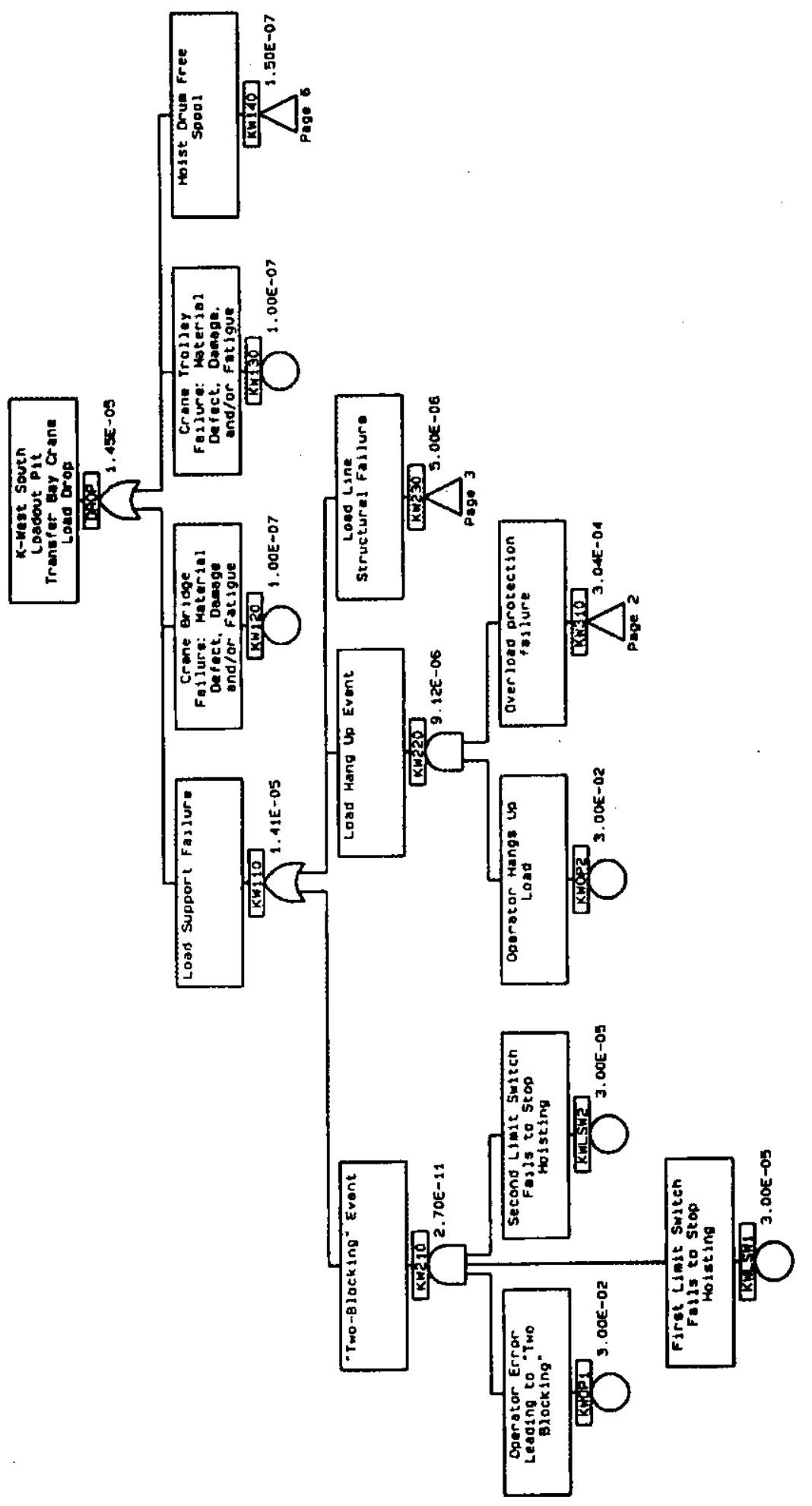


Figure 1. Multi-Canister Overpack Cask Drop in K West South Loadout Pit during Cask Loading System Alignment. (sheet 2 of 8 )

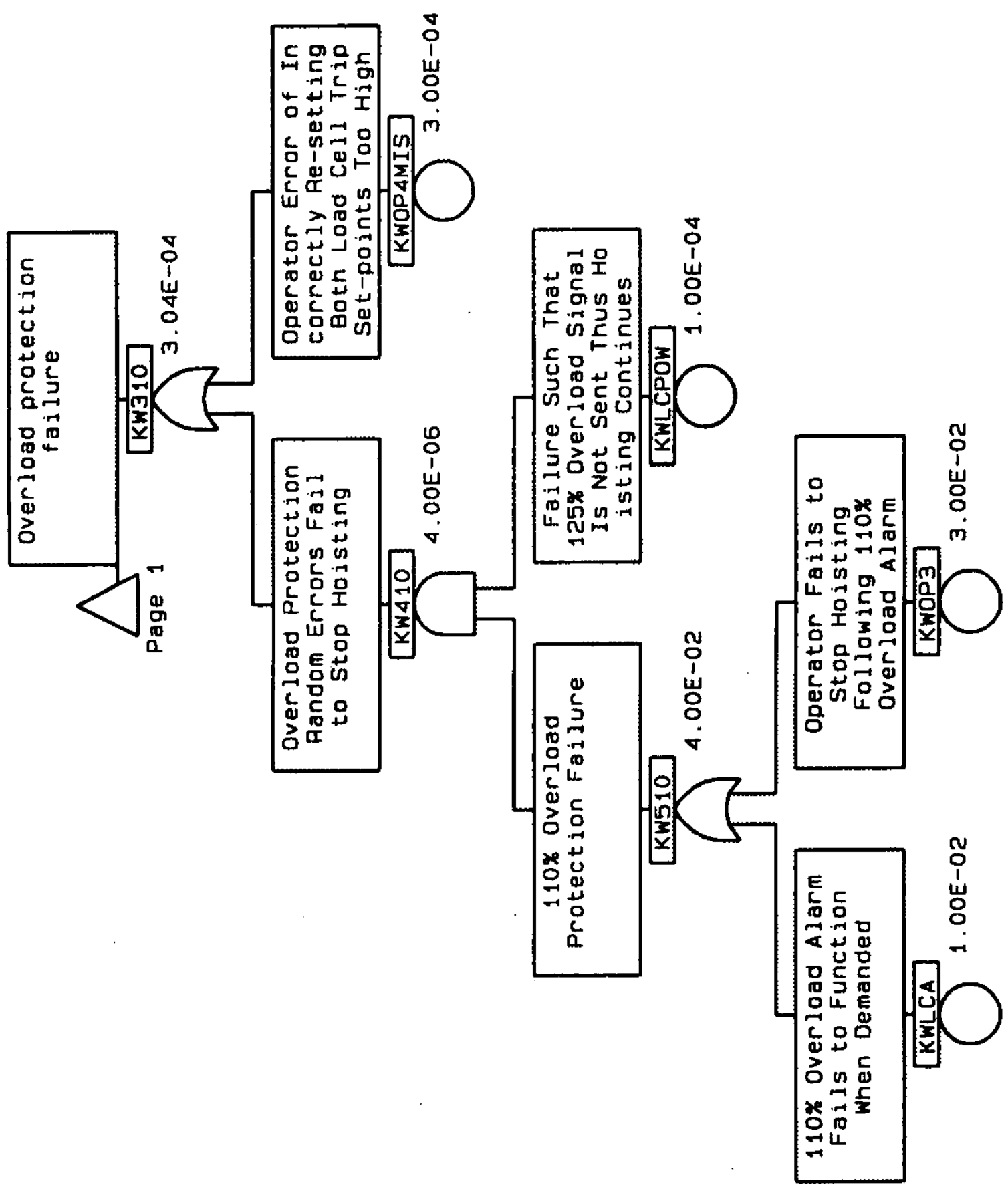




\section{SNF-5413 REV 0}

Figure 1. Multi-Canister Overpack Cask Drop in K West South Loadout Pit during Cask Loading System Alignment. (sheet 3 of 8)

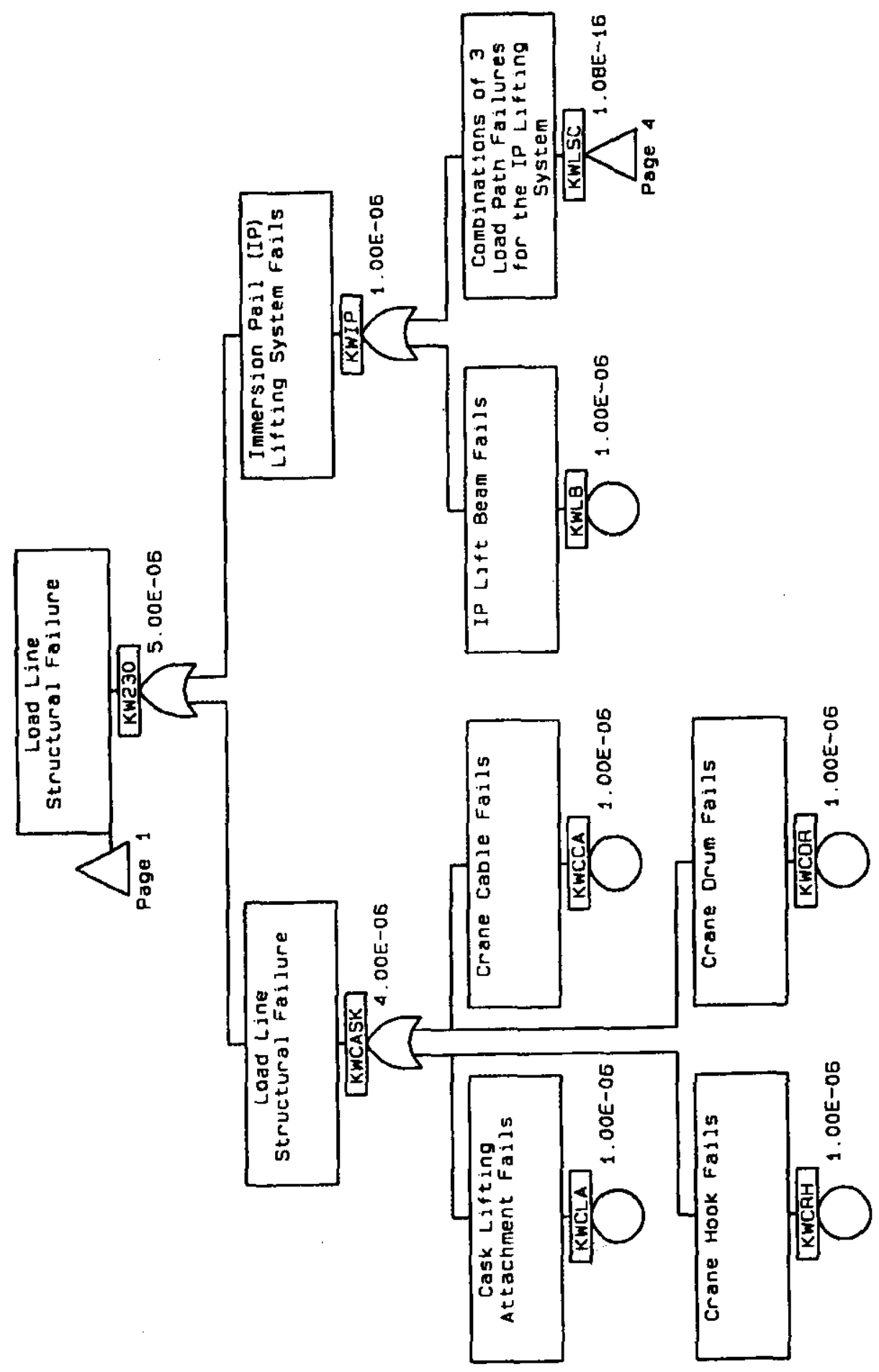




\section{SNF-5413 REV 0}

Figure 1. Multi-Canister Overpack Cask Drop in K West South Loadout Pit during Cask Loading System Alignment. (sheet 4 of 8)

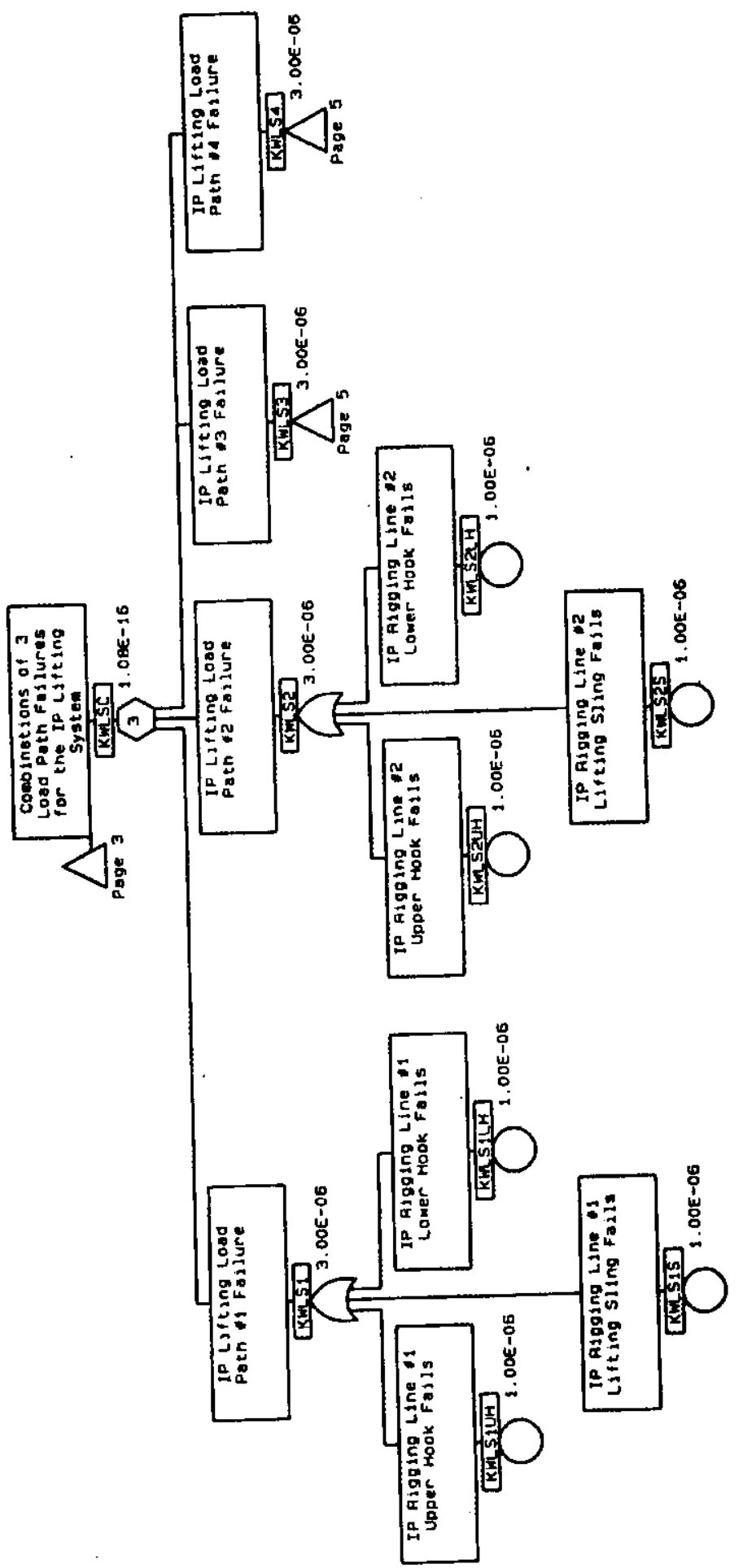


Figure 1. Multi-Canister Overpack Cask Drop in K West South Loadout Pit during Cask Loading System Alignment. (sheet 5 of 8)
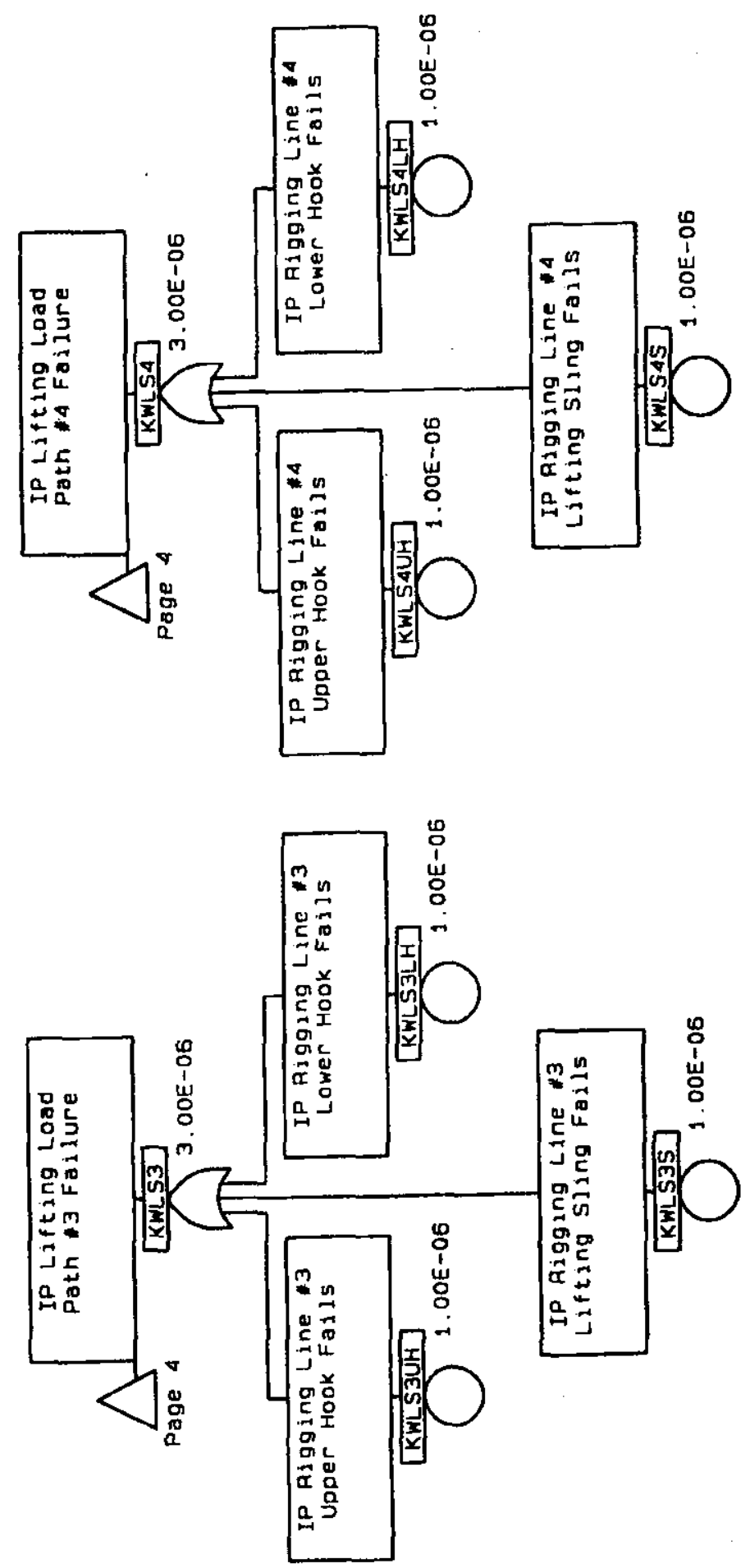


\section{SNF-5413 REV 0}

Figure 1. Multi-Canister Overpack Cask Drop in K West South Loadout Pit during Cask Loading System Alignment. (sheet 6 of 8)

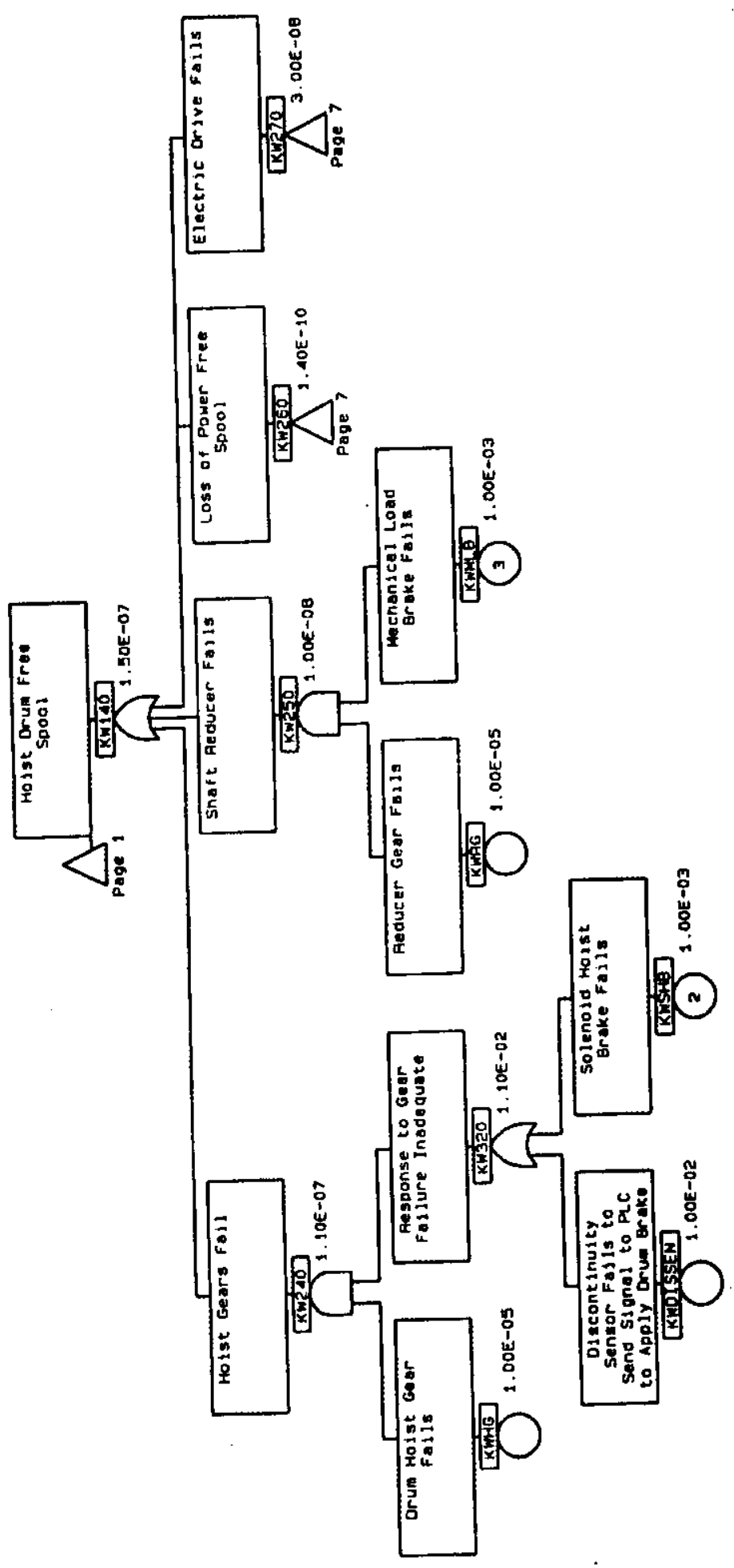




\section{SNF-5413 REV 0}

Figure 1. Multi-Canister Overpack Cask Drop in K West South Loadout Pit during Cask Loading System Alignment. (sheet 7 of 8)
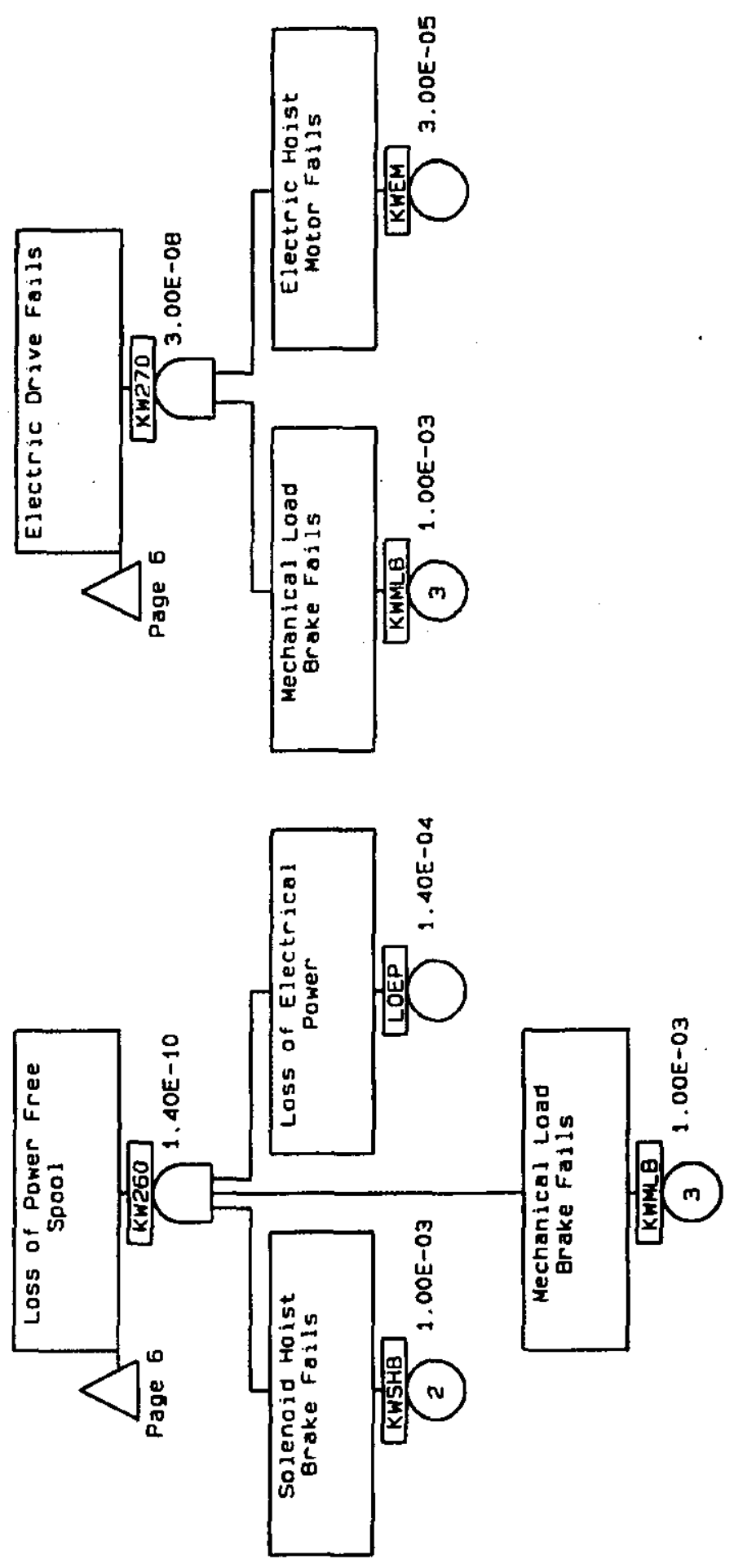
Figure 1. Multi-Canister Overpack Cask Drop in K West South Loadout Pit during Cask Loading System Alignment. (sheet 8 of 8 )

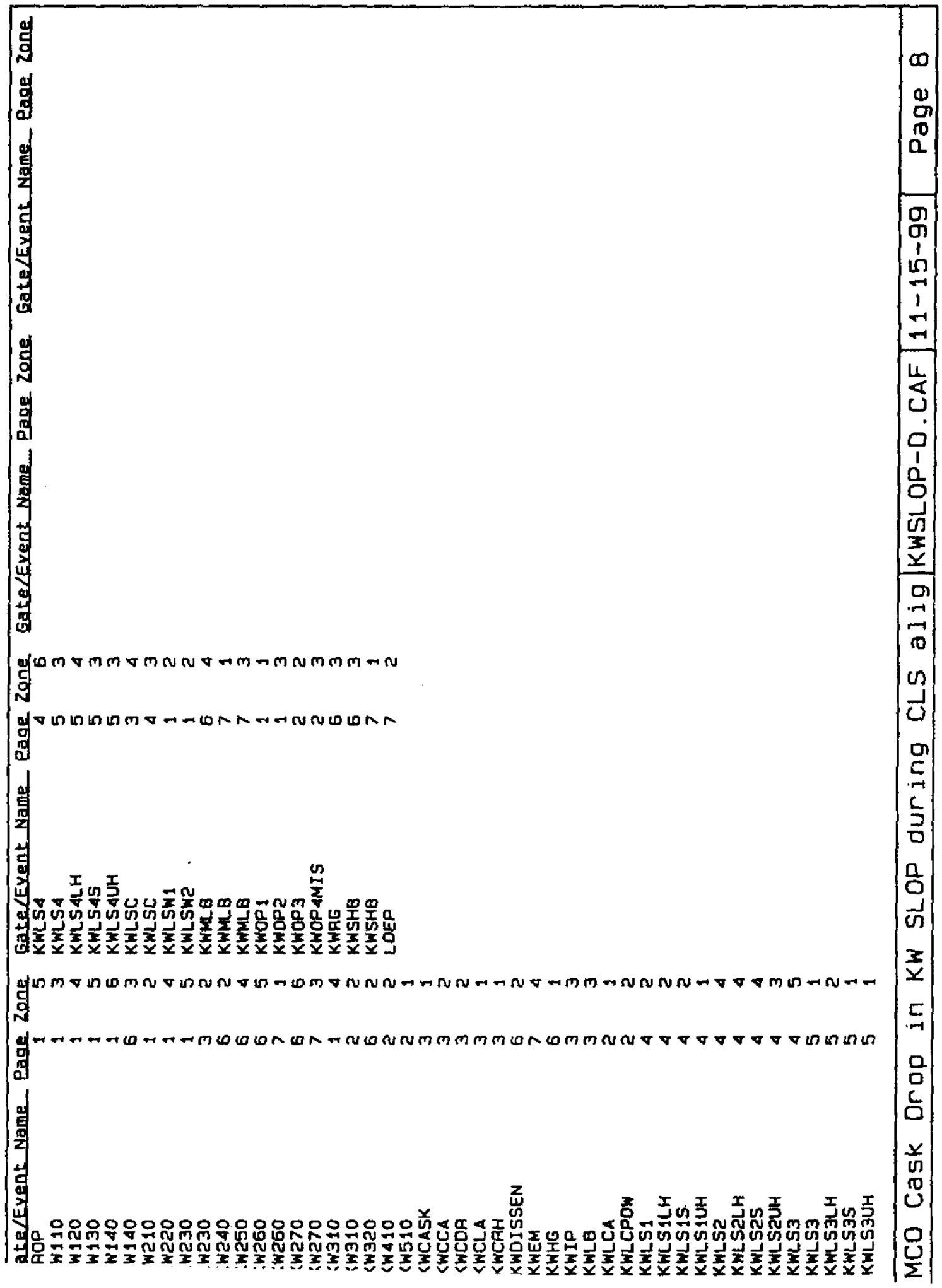


CLSDROP.CUT

Filter: 'ALL'

MODULE/EVENT NAME

1) DROP
1) KWOP2 KWOP4MIS
2) KWCCA
3) KWCDR
4) $\mathrm{KWCRH}$
5) XWCLA
6) KWLB
7) $\mathrm{KW130}$
8) $K W 120$
9) KWDISSEN KWHG
10) KWLCPOW KWOP2 KWOP3
11) KWLCA KWLCPOW KWOP2

12) KWEM KWMLB

13) KWMLB KWRG

14) KWHG KWSHB

15) KWMLB KWSHB LOEP

16) KWLSW1 KWLSW2 KWOP1

17) KWLSIUH KWLS3LH KWLS4UH

18) KWLSILH KWLS3LH KWLS4S

19) $\mathrm{KWLSIUH}$ KWLS3S KWLS4UH

20) KWLS1S KWLS3LH KWLS4S

21) KWLSILH KWLS2UH KWLS4S

22) KWLSIS KWLS2S KWLS3LH

23) KWLS1S KWLS3LH KWLS4UH

24) KWLSILH
CUTSET REPORT
Truncation limit: $1.00 E-30$

DESCRIPTION

Operator Error of Incorrectly Re-setting Crane Cable Fafls

Crane Drum Fails

Crane Hook Fails

Cask Lifting Attachment Fails

IP Lift Beam Fails

Crane Trolley Failure: Material Defect,

Crane Bridge Failure: Material Defect, D

Discontinuity Sensor Fails to Send Signa Drum Hoist Gear Fails

Fallure Such That $125 \%$ Overload Signal I Operator Hangs Up Load

operator Fails to Stop Hoisting Followin 110\% Overload $\mathrm{Al}$ arm Fails to Function Wh Failure Such That 125\% Overload Signal I Operator Hangs Up Load

Electric Hoist Motor Fails

Mechanical Load Brake Fails

Mechanical Load Brake Fails

Reducer Gear Fails

Drum Hoist Gear Fails

Solenoid Hoist Brake Fails

Mechanical Load Brake Falls

Solenoid Hoist Brake Fails

Loss of Electrical Power

First Limit Switch Fails to Stop Hoistin

Second Limit Switch Falls to Stop Hoisti

Operator Error Leading to "Two Blocking"

IP Rigging Line \#l Upper Hook Fails

IP Rigging Line \#3 Lower Hook Fails

IP Rigging Line \#4 Upper Hook Fails

IP Rigging Line \#I Lower Hook Fails

IP Rigging Line \#3 Lower Hook Fails

IP Rigging Line \#4 Lifting Sling Fails

IP Rigging Line \#l Upper Hook Fails

IP Rigging Line \#3 Lifting Sling Fails

IP Rigging Line *4 Upper Hook Fails

IP Rigging Line \#l Lifting Sling Fails

IP Rigging Line \#3 Lower Hook Fails

IP Rigging Line \#4 Lifting sling Falls

IP Rigging Line \#l Lower Hook Fails

IP Rigging Line \#2 Upper Hook Fails

IP Rigging Line *4 Lifting Sling Fails

IP Rigging Line *l Lifting Sling Falls

IP Rigging Line \#2 Lifting Sling Fails

IP Rigging Line 3 Lower Hook Fails

IP Rigging Line \#l Lifting Sling Fails

IP Rigging Line *3 Lower Hook Fails

IP Rigging Line \#4 Upper Hook Fails

IP Rigging Line \#l Lower Hook Fails
B.E.

PROB.

PROB.

\section{$\star 1.45 \mathrm{E}-05$}

3.00E-02

$3.00 \mathrm{E}-04$

$1.00 \mathrm{E}-06$

$1.00 \mathrm{E}-06$

$1.00 \mathrm{E}-06$

$1.00 \mathrm{E}-06$

$1.00 \mathrm{E}-06$

$1.00 \mathrm{E}-07$

$1.00 \mathrm{E}-07$

$1.00 \mathrm{E}-02$

$1.00 \mathrm{E}-05$

1. $00 \mathrm{E}-04$

3. $00 \mathrm{E}-02$

3. $00 E-02$

$1.00 E-02$

$1.00 E-04$

3. $00 \mathrm{E}-02$

3. $00 \mathrm{E}-05$

$1.00 \mathrm{E}-03$

$1.00 \mathrm{E}-03$

$1.00 \mathrm{E}-05$

1. $00 \mathrm{E}-05$

1. $00 \mathrm{E}-03$

$1.00 \mathrm{E}-03$

$1.00 E-03$

$1.40 \mathrm{E}-04$

3. $00 \mathrm{E}-05$

3. $00 \mathrm{E}-05$

3. $00 \mathrm{E}-02$

1. $00 E-06$

$1.00 E-06$

$1.00 \mathrm{E}-06$

$1.00 E-06$

$1.00 \mathrm{E}-06$

1. $00 \mathrm{E}-06$

1. $00 \mathrm{E}-06$

$1.00 E-06$

1. $00 \mathrm{E}-06$

$1.00 E-06$

$1.00 E-06$

$1.00 \mathrm{E}-06$

$1.00 E-06$

$1.00 \mathrm{E}-06$

$1.00 E-06$

1. $00 E-06$

$1.00 E-06$

1. $00 \mathrm{E}-06$

1. $00 \mathrm{E}-06$

$1.00 \mathrm{E}-06$

$1.00 \mathrm{E}-06$

1.00 E-06

\subsection{E-06}

1.00E-06

$1.00 E-06$

1.00E-06

$1.00 E-06$

$1.00 \mathrm{E}-06$

1. $00 \mathrm{E}-07$

1. $00 \mathrm{E}-07$

$1.00 E-07$

9.00E-08

$3.00 E-08$

$3.00 E-08$

1.00E-08

1.00E-08

1. $40 \mathrm{E}-10$

2.70E-11

$1.00 E-18$

1. $00 \mathrm{E}-18$

$1.00 E-18$

$1.00 E-18$

1. $00 \mathrm{E}-18$

$1.00 E-18$

$1.00 \mathrm{E}-18$

$1.00 E-18$ 
CLSDROP.CUT

Filter: 'ALL'

MODULE/EVENT NAME

\section{- - - - - - - - -}

KWLS2S

KWLS3LH

25) KWLSIUH

KWLS3LH

KWLS4S

26) KWLSILH

KWLS2LH

KWLS3S

27) KWLS1UH

KWLS2LH

KWLS3LH

28) KWLSIUH

KWLS3LH

KWLS4LH

29) KWLSIS

KWLS3LH

KWLS4LH

30) KWLSILH

KWLS3UH

KWLS4LH

31) KWLSIUH

KWLS2S

KWLS3LH

32) KWLS2UH

KWLS3S

KWLS4UH

33) KWLS1LH

KWLS3S

KWLS4LH

34) KWLSIS

KWLS3S

KWLS4LH

35) KWLSIUH

KWLS2S

KWLS3UH

36) KWLSIUH

KWLS2LH

KWLS4S

37) KWLSILH

KWLS2UH

KWLS3LH

38) KWLSILH

KWLS3S

KWLS4S

39) KWLSILH

KWLS3LH

KWLS4UH

40) KWLS1S

XWLS2LH

KWLS4S

41) KWLSIS

KWLS2S

\section{CUTSET REPORT}

Truncation Limit: $1.00 E-30$

DESCRIPTION

IP Rigging Line \#2 Lifting Sling Fails

IP Rigging Line \#3 Lower Hook Fails

IP Rigging Line \#1 Upper Hook Fails

IP Rigging Line \#3 Lower Hook Fails

IP Rigging Line \#4 Lifting Sling Fails

IP Rigging Line *I Lower Hook Fails

IP Rigging Line *2 Lower Hook Fails

IP Rigging Line *3 Lifting Sling Fails

IP Rigging Line \#1 Upper Hook Fails

IP Rigging Line \#2 Lower Hook Fails

IP Rigging Line \#3 Lower Hook Fails

IP Rigging Line \#1 Upper Hook Fails

IP Rigging Line \#3 Lower Hook Fails

IP Rigging Line \#4 Lower Hook falls

IP Rigging Line \#l Lifting Sling Fails

IP Rigging Line *3 Lower Hook Fails

IP Rigging Line \#4 Lower Hook Fails

IP Rigging Line \# 1 Lower Hook Fails

IP Rigging Line \#3 Upper Hook Fails

IP Rigging Line \#4 Lower Hook Fails

IP Rigging Line \#1 Upper Hook Fails

IP Rigging Line $\# 2$ Lifting Sling Fails

IP Rigging Line \#3 Lower Hook Fails

IP Rigging Line \#2 Upper Hook Fails

IP Rigging Line \#3 Lifting Sling Fails

IP Rigging Line \#4 Upper Hook Falls

IP Rigging Line \#1 Lower Hook Fails

IP Rigging Line \#3 Lifting Sling Fails

IP Rigging Line \#4 Lower Hook Fails

IP Rigging line \#l Lifting Sling Fails

IP Rigging Line \#3 Lifting Sling Fails

IP Rigging Line \#4 Lower Hook Fails

IP Rigging Line \#l Upper Hook Fails

IP Rigging Line \#2 Lifting Sling Fails

IP Rigging Line \#3 Upper Hook Fails

IP Rigging Line \#1 Upper Hook Fails

IP Rigging Line \#2 Lower Hook Fails

IP Rigging Line \#4 Lifting Sling Fails

IP Rigging Line 1 Lower Hook Falls

IP Rigging Line $\$ 2$ Upper Hook Fafls

IP Rigging Line \#3 Lower Hook Fails

IP Rigging Line \#1 Lower Hook Fails

IP Rigging Line *3 Lifting Sling Fails

IP Rigging Line *4 Lifting Sling Fails

IP Rigging Line \#1 Lower Hook Fails

IP Rigging Line \#3 Lower Hook Fails

IP Rigging Line \#4 Upper Hook Fails

IP Rigging Line \#l Lifting sing Fails

IP Rigging Line \#2 Lower Hook Fails

IP Rigging Line \#4 Lifting Sling Fails

IP Rigging Line \#l Lifting Siing Fails

IP Rigging Line \#2 Lifting Sling Fails
B.E.

PROB.

$\mathrm{MOD} . / \mathrm{CS}$.

PROB.

$1.00 E-06$

$1.00 \mathrm{E}-06$

1. $00 \mathrm{E}-06$

$1.00 E-06$

1.00 E-06

1.00 E-06

1.00E-06

$1.00 E-06$

1.00E-06

1.00E-06

$1.00 \mathrm{E}-06$

1.00E-06

$1.00 \mathrm{E}-06$

1.00E-06

1. $00 \mathrm{E}-06$

$1.00 \mathrm{E}-06$

1. $00 \mathrm{E}-06$

1. $00 \mathrm{E}-06$

1. 00 E-06

$1.00 \mathrm{E}-06$

1. 00 E-06

1. $00 \mathrm{E}-06$

1. 00 E-06

1. $00 \mathrm{E}-05$

$1.00 \mathrm{E}-06$

1. $00 \mathrm{E}-06$

$1.00 E-06$

1. $00 \mathrm{E}-06$

$1.00 \mathrm{E}-06$

$1.00 \mathrm{E}-06$

1. $00 \mathrm{E}-06$

1. $00 \mathrm{E}-06$

1. $00 \mathrm{E}-06$

1. 00 E-06

1. $00 \mathrm{E}-06$

1. $00 \mathrm{E}-06$

1. $00 \mathrm{E}-06$

$1.00 \mathrm{E}-06$

1. $00 \mathrm{E}-06$

1. $00 \mathrm{E}-06$

$1.00 E-06$

$1.00 \mathrm{E}-06$

$1.00 \mathrm{E}-06$

1.00E-06

$1.00 \mathrm{E}-06$

$1.00 \mathrm{E}-06$

1. $00 \mathrm{E}-06$

1. $00 \mathrm{E}-06$

1. $00 \mathrm{E}-06$

$1.00 \mathrm{E}-06$

1. $00 \mathrm{E}-06$

1.00E-06
$1.00 E-18$

$1.00 E-18$

$1.00 \mathrm{E}-18$

$1.00 E-18$

$1.00 E-18$

1.00E-18

$1.00 E-18$

$1.00 E-18$

$1.00 \mathrm{E}-18$

1.00E-18

1.00E-18

$1.00 E-18$

$1.00 E-18$

$1.00 E-18$

1.00E-18

$1.00 \mathrm{E}-18$

1. $00 E-18$ 
CLSDROP.CUT

Filter: 'ALL'

\section{MODULE/EVENT NAME}

KWLS3UH

42) KWLSILH

KWLS2S

KWLS3UH

43) KWLSIUH KWLS2S

KWLS3S

44) KWLSIS

KWLS2S

KWLS3S

45) KWLSILH KWLS2S KWLS3S

46) KWLS2S KWLS3S KWL.S4UH

47) KWLSIUH KWLS3S KWLS4S

48) KWLS2LH KWLS3S KWLS4UH

49) KWLSIUH KWLS2LH KWLS3UH

50) KWLSIS KWLS2LH KWLS3UH

51) KWLS1LH KWLS2LH KWLS3UH

52) KWLSIUH KWLS2LH KWLS3S

53) KWLSIS KWLS2LH KWLS3S

54) KWLS2S KWLS3LH KWLS4LH

55) KWLS2LH KWLS3LH KWLS4LH

56) KWLSIS KWLS2LH KWLS3LH

57) KWLSILH KWLS2LH KWLS3LH

58) KWLSIUH KWLS2UH KWLS4UH
CUTSET REPORT

Truncation Limit: $\quad$. .00E-30

\section{DESCRIPTION}

IP Rigging Line \#3 Upper Hook Fails

IP Rigging Line "I Lower Hook Fails

IP Rigging Line 2 Lifting sling Falls

IP Rigging Line \#3 Upper Hook Fails

IP Rigging Line \#1 Upper Hook Fails

IP Rigging Line \#2 Lifting Sling Falls

IP Rigging Line \#3 Lifting Sling Falls

IP Rigging Line \#l Lifting Sling Fails

IP Rigging Line \#2 Lifting sling Fails

IP Rigging Line \#3 Lifting Sling Fails

IP Rigging Line \#1 Lower Hook Fails

IP Rigging Line "2 Lifting Sling Fails

IP Rigging Line \#3 Lifting sling Fails

IP Rigging Line \#2 Lifting sling Fails

IP Rigging Line \#3 lifting sling Fails

IP Rigging Line \#4 Upper Hook Fails

IP Rigging Line \#1 Upper Hook Fails

IP Rigging Line \#3 Lifting sling Falls

IP Rigging Line \#4 Lifting Sling Falls

IP Rigging Line \#2 Lower Hook Fails

IP Rigging Line \#3 Lifting Sling Fails

IP Rigging Line \#4 Upper Hook Fails

IP Rigging Line \#1 Upper Hook Falls

IP Rigging Line \#2 Lower Hook Fails

IP Rigging Line \#3 Upper Hook Fails

IP Rigging Line \#l Lifting sling Fails

IP Rigging Line \#2 Lower Hook Fails IP Rigging Line \#3 Upper Hook Fails IP Rigging Line \#l Lower Hook Fails IP Rigging Line \#2 Lower Hook Fails IP Rigging Line \#3 Upper Hook Fails IP Rigging Line \#l Upper Hook Fails IP Rigging Line \#2 Lower Hook Fails IP Rigging Line \#3 Lifting sling Fails IP Rigging Line "l Lifting Sling Fails IP Rigging Line \#2 Lower Hook Fails IP Rigging Line \#3 Lifting Sling Fails IP Rigging Line \#2 Lifting sling fails IP Rigging Line \#3 Lower Hook Fails IP Rigging Line \#4 Lower Hook Fails IP Rigging Line \#2 Lower Hook Fails IP Rigging Line \#3 Lower Hook Fails IP Rigging Line \#4 Lower Hook Fails IP Rigging Line \#1 Lifting Sling Fails IP Rigging Line \#2 Lower Hook Fails IP Rigging Line \#3 Lower Hook Fails IP Rigging Line \#l Lower Hook Fails IP Rigging Line \#2 Lower Hook Fails IP Rigging Line \#3 Lower Hook Fails IP Rigging Line \#l Upper Hook Fails IP Rigging Line \#2 Upper Hook Fails IP Rigging Line \#4 Upper Hook Fails
1-15-99 10:59 Page 3

B.E. MOD./CS.

PROB. PROB.

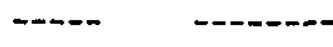

$1.00 \mathrm{E}-06$

$1.00 \mathrm{E}-06 \quad 1.00 \mathrm{E}-18$

$1.00 \mathrm{E}-06$

$1.00 \mathrm{E}-06$

$1.00 E-06$

$1.00 \mathrm{E}-06$

$1.00 E-06$

$1.00 \mathrm{E}-06$

$1.00 E-06$

$1.00 E-06$

$1.00 \mathrm{E}-06$

$1.00 E-06$

$1.00 E-06$

$1.00 \mathrm{E}-06$

1. $00 \mathrm{E}-06$

1. $00 \mathrm{E}-06$

$1.00 \mathrm{E}-06$

$1.00 \mathrm{E}-06$

$1.00 \mathrm{E}-06$

1. $00 \mathrm{E}-06$

$1.00 \mathrm{E}-06$

$1.00 \mathrm{E}-06$

$1.00 \mathrm{E}-06$

1. $00 \mathrm{E}-06$

$1.00 E-06$

$1.00 \mathrm{E}-06$

1. $00 \mathrm{E}-06$

1.00 E-06

$1.00 \mathrm{E}-06$

$1.00 \mathrm{E}-06$

1. $00 \mathrm{E}-06$

$1.00 \mathrm{E}-06$

$1.00 \mathrm{E}-06$

1. $00 \mathrm{E}-06$

$1.00 \mathrm{E}-06$

1. $00 \mathrm{E}-06$

1. O0E-06

$1.00 \mathrm{E}-06$

1. $00 \mathrm{E}-06$

1. $00 \mathrm{E}-06$

$1.00 \mathrm{E}-06$

$1.00 \mathrm{E}-06$

$1.00 \mathrm{E}-06$

1. $00 \mathrm{E}-06$

$1.00 E-06$

$1.00 \mathrm{E}-06$

1. $00 \mathrm{E}-06$

$1.00 \mathrm{E}-06$

1. $00 \mathrm{E}-06$

$1.00 \mathrm{E}-06$

$1.00 E-06$

1. 00 E-06

\section{1. $00 \mathrm{E}-18$}

1.00E-18

$1.00 \mathrm{E}-18$

$1.00 E-18$

1. $00 \mathrm{E}-18$

1.00E-18

$1.00 E-18$

$1.00 E-18$

$1.00 E-18$

$1.00 E-18$

$1.00 E-18$

$1.00 \mathrm{E}-18$

1.00E-18

$1.00 E-18$

$1.00 E-18$

$1.00 E-18$

$1.00 \mathrm{E}-18$ 
CLSDROP.CUT

F1lter: 'ALL'

MOQULE/EVENT NAME

59) KWLS1S

KWLSZUH

KWLS4UH

60) KWLSILH

KWLS2UH

KWLS4UH

61) KWLSIUH

KWLS2UH

KWLS4S

62) KWLSIUH

KWLS2UH

KWLS3S

63) KWLSILH

KWLS2LH

KWLS4UH

64) KWLSIUH

KWLS2UH

KWLS3LH

65) KWLS1S

KWLS2UH

KWLS3LH

66) KWLS1LH

KWLS2UH

KWLS3S

67) KWLSIS

KWLS2S

KWLS4S

68) KWLSIUH KWLS2S

KWLS4UH

69) KWLSILH KWLS3UH

KWLS4S

70) KWLSIUH

KWLS2S

KWLS4S

71) KWLSILH

KWLS2S

KWLS4UH

72) KWLSILH

KWLS2S

KWLS4S

73) KWLS1UH

KWLS2S

KWLS4LH

74) KWLS1S

KWLS2S

KWLS4LH

75) KWLS1LH

KHLS2S

KWLS4LH

76) KWLSIUH
CUTSET REPORT

Truncation Limit: $1.00 E-30$

\section{DESCRIPTION}

IP Rigging Line \#1 Lifting Sling Fails

IP Rigging Line \#2 Upper Hook Fails

IP Rigging Line \#4 Upper Hook Fafls

IP Rigging Line \#1 Lower Hook Fails

IP Rigging Line \#2 Upper Hook Fails

IP Rigging Line \#4 Upper Hook Fails

IP Rigging Line \#I Upper Hook Fails

IP Rigging Line \#2 Upper Hook Fails

IP Rigging Line \#4 Lifting Sling Falls

IP Rigging Line \#l Upper Hook Fails

IP Rigging Line \#2 Upper Hook Fails

IP Rigging Line \#3 Lifting Sling Fails

IP Rigging Line \#l Lower Hook fails

IP Rigging line \#2 Lower Hook Falls

IP Rigging Line $\# 4$ Upper Hook Falls

IP Rigging Line *l Upper Hook Fails

IP Rigging Line \#2 Upper Hook Fails

IP Rigging Line \#3 Lower Hook Fails

IP Rigging Line \#1 Lifting Sling Fails

IP Rigging Line \#2 Upper Hook Falls

IP Rigging Line \#3 Lower Hook Fails

IP Rigging Line \#1 Lower Hook Fails

IP Rigging Line \#2 Upper Hook Fails

IP Rigging Line \#3 Lifting Sling fails

IP Rigging Line \#l Lifting Sling Fails

IP Rigging Line \#2 Lifting 57 ing Fails

IP Rigging Line \#4 Lifting Sling Fails

IP Rigging Line \#l Upper Hook Fails

IP Rigging Line \#2 Lifting Sling Fails

IP Rigging Line \#4 Upper Hook Fails

IP Rigging Line \#1 Lower Hook Fatls

IP Rigging Line \#3 Upper Hook Fails

IP Rigging Line \#4 Lifting sling Fails

IP Rigging Line \#l Upper Hook Fails

IP Rigging Line \#2 Lifting Sling Fails

IP Rigging Line \#4 Lifting Sling Fails

IP Rigging Line \#l Lower Hook Falls

IP Rigging Line \#2 Lifting Sling Fails

IP Rigging Line \#4 Upper Hook fails

IP Rigging Line \#l Lower Hook Fails

IP Rigging Line \#2 Lifting SIing Fails

IP Rigging Line \#4 Lifting Sling Fails

IP Rigging Line \#I Upper Hook Fails

IP Rigging Line \#2 Lifting Sling Fails

IP Rigging Line \#4 Lower Hook Fails

IP Rigging Line \#l Lifting Sling Fails

IP Rigging Line \#2 Lifting Sling Fails

IP Rigging Line \#4 Lower Hook Fails

IP Rigging Line \#l Lower Hook Fails

IP Rigging Line "2 Lifting Sling Fails

IP Rigging Line $\# 4$ Lower Hook Fails

IP Rigging Line \#1 Upper Hook Fails
B.E.

PROB.

$/ C S$

$1.00 \mathrm{E}-06$

$1.00 E-06$

$1.00 E-06$

$1.00 \mathrm{E}-06$

$1.00 E-06$

$1.00 E-06$

$1.00 E-06$

$1.00 \mathrm{E}-06$

1.00E-06

$1.00 \mathrm{E}-06$

1. $00 \mathrm{E}-06$

1. 00E-06

$1.00 \mathrm{E}-06$

$1.00 \mathrm{E}-06$

1. $00 \mathrm{E}-06$

1. $00 \mathrm{E}-06$

$1.00 \mathrm{E}-06$

1. $00 \mathrm{E}-06$

1. $00 \mathrm{E}-06$

$1.00 \mathrm{E}-06$

$1.00 \mathrm{E}-06$

$1.00 \mathrm{E}-06$

$1.00 E-06$

$1.00 \mathrm{E}-06$

1. $00 \mathrm{E}-06$

1. $00 \mathrm{E}-06$

$1.00 E-06$

1. $00 \mathrm{E}-06$

1. $00 \mathrm{E}-06$

$1.00 E-06$

$1.00 \mathrm{E}-06$

$1.00 \mathrm{E}-06$

1. $00 \mathrm{E}-06$

1. $00 \mathrm{E}-06$

1. $00 \mathrm{E}-06$

1. $00 \mathrm{E}-06$

$1.00 \mathrm{E}-06$

$1.00 \mathrm{E}-06$

$1.00 \mathrm{E}-06$

$1.00 E-06$

1.00E-06

1. $00 \mathrm{E}-06$

$1.00 \mathrm{E}-06$

$1.00 \mathrm{E}-06$

$1.00 \mathrm{E}-06$

1. $00 \mathrm{E}-06$

1.00E-06

$1.00 \mathrm{E}-06$

1. $00 \mathrm{E}-06$

$1.00 \mathrm{E}-06$

1. $00 \mathrm{E}-06$

1.00E-06 1.00E-18
$1.00 \mathrm{E}-18$

$1.00 E-18$

$1.00 E-18$

$1.00 \mathrm{E}-18$

$1.00 E-18$

$1.00 E-18$

1. $00 \mathrm{E}-18$

$1.00 E-18$

$1.00 E-18$

$1.00 E-18$

$1.00 E-18$

$1.00 E-18$

$1.00 E-18$

1.00E-18

$1.00 E-18$

1.00E-18

$1.00 \mathrm{E}-18$ 
CLSDROP.CUT

Fifter: 'ALL'

MODULE/EVENT NAME

KWLS2LH

KWLS4UH

77) KWLS1S

KWLS2LH

KWLS4UH

78) KWLSILH

XWLSZUH

KWLS4LH

79) KWLSIUH

KWLS3UH

KWLS4LH

80) KWLSIS

KWLS2UH

KWLS3UH

81) KWLS1LH

KWLS2LH

KWLS4S

82) XWLSIUH

KWLSZLH

KWLS4LH

83) KWLSIS

KWLSZLH

KWLS4LH

84) KWLSILH

KWLS2LH

KWLS4LH

85) KWLS2UH

KWLS3UH

KWLS4UH

86) KWLS2S

KWLS3UH

KWLS4UH

87) KWLS2L.H

KWLS3UH

KWLS SUH

88) KWLS2UH

KWLS3UH

KWLS4S

89) KWLS2S

KWLS3UH

KWLS4S

90) KWLS2LH

KWLS3UH

KWLS4S

91) KWLS2UH

KWLS3UH

KHLS4LH

92) KWLS2S

KWLS3UH

KWLS4LH

93) KWLS2LH

KWLS3UH
CUTSET REPORT

Truncation Limit: $1.00 E-30$

\section{DESCRIPTION}

IP Rigging Line \#2 Lower Hook Fails

IP Rigging Line \#4 Upper Hook Falls

IP Rigging Line "1 Lifting Sling Fails

IP Rigging Line $\# 2$ Lower Hook Fails

IP Rigging Line \#4 Upper Hook Fails

IP Rigging Line \#I Lower Hook Fails

IP Rigging Line \#2 Upper Hook Fafls

IP Rigging Line \#4 Lower Hook Fails

IP Rigging line \#l Upper Hook Fails

IP Rigging Line \#3 Upper Hook Fails

IP Rigging Line \#4 Lower Hook Fails

IP Rigging Line \#1 Lifting sling Fails

IP Rigging Line \#2 Upper Hook Falls

IP Rigging Line *3 Upper Hook Fails

IP Rigging Line \#1 Lower Hook Fails

If Rigging Line \#2 Lower Hook Fails

IP Rigging Line \#4 Lifting Sling Fafls

IP Rigging Line "1 Upper Hook Fails

IP Rigging Line \#2 Lower Hook Falls

IP Rigging Line \#4 Lower Hook Fails

IP Rigging Line \#l Lifting Sling Fails

IP Rigging Line \#2 Lower Hook Fails

IP Rigging Line \#4 Lower Hook Fails

IP Rigging Line \#1 Lower Hook Fails

IP Rigging Line \#2 Lower Hook Fails

IP Rigging Line \#4 Lower Hook Fails

IP Rigging Line \#2 Upper Hook Fails

IP Rigging Line \#3 Upper Hook Fails

IP Rigging Line \#4 Upper Hook Fails

IP Rigging Line \#2 Lifting Sling Fails

IP Rigging Line \#3 Upper Hook Fails

IP Rigging Line *4 Upper Hook Fails

IP Rigging Line \#2 Lower Hook Fails

IP Rigging Line \#3 Upper Hook Fafls

IP Rigging Line \#4 Upper Hook Fails

IP Rigging Line *2 Upper Hook Fails

IP Rigging Line \#3 Upper Hook Fails

IP Rigging Line \#4 Lifting Sling Fails

IP Rigging Line "2 Lifting Sling Fails

IP Rigging Line \#3 Upper Hook fails

IP Rigging Line \#4 Lifting sling Fails

IP Rigging Line \#2 Lower Hook Fails

IP Rigging Line \#3 Upper Hook Fails

IP Rigging Line \#4 Lifting sling Fails

IP Rigging Line $\$ 2$ Upper Hook Fails

IP Rigging Line \#3 Upper Hook Fails

IP Rigging Line \#4 Lower Hook Fails

IP Rigging Line \#2 Lifting S1ing Fails

IP Rigging Line \#3 Upper Hook Fails

IP Rigging Line \#4 Lower Hook Fails

IP Rigging Line \#2 Lower Hook Fails

IP Rigging Line \#3 Upper Hook Fails

\section{-15-99 10:59 Page 5}

B.E. MOD./CS.

PROB. PROB.

PROB.

$1.00 E-06$

$1.00 \mathrm{E}-06$

$1.00 \mathrm{E}-06$

$1.00 E-06$

$1.00 \mathrm{E}-06$

$1.00 E-06$

$1.00 E-06$

$1.00 \mathrm{E}-06$

$1.00 E-06$

1.00E-06

1.00E-06

$1.00 E-06$

1. $00 \mathrm{E}-06$

$1.00 \mathrm{E}-06$

1. $00 \mathrm{E}-06$

1. $00 \mathrm{E}-06$

$1.00 \mathrm{E}-06$

1. $00 \mathrm{E}-06$

1.00E-06

$1.00 E-06$

1. $00 \mathrm{E}-06$

1.00E-06

$1.00 \mathrm{E}-06$

$1.00 \mathrm{E}-06$

1. 00 E-06

$1.00 \mathrm{E}-06$

$1.00 \mathrm{E}-06$

1. $00 \mathrm{E}-06$

1.00E-06

1. $00 \mathrm{E}-06$

$1.00 E-06$

1. $00 \mathrm{E}-06$

$1.00 \mathrm{E}-06$

$1.00 \mathrm{E}-06$

$1.00 \mathrm{E}-06$

$1.00 \mathrm{E}-06$

1. $00 \mathrm{E}-06$

$1.00 \mathrm{E}-06$

1. $00 \mathrm{E}-06$

1. $00 \mathrm{E}-06$

$1.00 \mathrm{E}-06$

$1.00 \mathrm{E}-06$

1. 00 E-06

1. $00 \mathrm{E}-06$

1.00E-06

1. 00 E-06

$1.00 \mathrm{E}-06$

$1.00 \mathrm{E}-06$

$1.00 E-06$

$1.00 \mathrm{E}-06$

$1.00 \mathrm{E}-06$

1. 00 E-06

\section{$1.00 E-18$}

$1.00 E-18$

$1.00 E-18$

$1.00 E-18$

$1.00 E \sim 18$

$1.00 E-18$

$1.00 E-18$

$1.00 E-18$

$1.00 E-18$

1.00E-18

$1.00 E-18$

$1.00 E-18$

$1.00 E-18$

1. $00 \mathrm{E}-18$

1.00E-18

$1.00 E-18$

$1.00 E-18$ 
CISDROP.CUT

Filter: 'ALL'
CUTSET REPORT

Truncation Limit: $1.00 E-30$

\section{DESCRIPTION}

IP Rigging Line *4 Lower Hook Fails

IP Rigging Line \#l Upper Hook Fails

IP Rigging Line \#2 Upper Hook Fails

IP Rigging Line \#3 Upper Hook Fails

IP Rigging Line \#l Lifting Sling Fails

If Rigging line $* 2$ Lifting sling fails

IP Rigging Line \#4 Upper Hook Fails

IP Rigging Line \#l Lower Hook Fails

IP Rigging Line \#2 Upper Hook Fails

IP Rigging Line \#3 Upper Hook Fails

IP Rigging Line *2 Upper Hook Fails

IP Rigging Line \#3 Lifting sling Fails

IP Rigging Line *4 Lifting sling Fails

IP Rigging Line \#2 Lifting sling Fails

IP Rigging Line \#3 Lifting. Sling Fails

IP Rigging line \#4 Lifting Siing Fails

IP Rigging Line \#2 Lower Hook Fails

IP Rigging Line *3 Lifting Sling Fails

IP Rigging Line \#4 Lifting sling fails

IP Rigging Line \#2 Upper Hook Fails

IP Rigging Line \#3 Lifting Sling Fails

IP Rigging Line *4 Lower Hook Fails

IP Rigging Line \#2 Lifting Sling Fails

IP Rigging line *3 Lifting Sling Fails

IP Rigging Line \#4 Lower Hook Fails

IP Rigging Line \#2 Lower Hook Fails

IP Rigging Line \#3 Lifting sling Fails

IP Rigging Line \#4 Lower Hook Fails

IP Rigging Line \#2 Upper Hook Fails

IP Rigging Line \#3 Lower Hook Fails

IP Rigging Line \#4 Upper Hook Fails

IP Rigging Line \#2 Lifting Siting Falls

IP Rigging Line \#3 Lower Hook Fails

IP Rigging Line *4 Upper Hook Fails

IP Rigging Line \#2 Lower Hook Fails

IP Rigging Line $\$ 3$ Lower Hook Fails

IP Rigging Line \#4 Upper Hook Fails

IP Rigging Line U2 Upper Hook Fails

IP Rigging Line \#3 Lower Hook Fails

IP Rigging Line \#4 Lifting Sling Fails

IP Rigging Line \#2 Lifting Sling Fails

IP Rigging Line \#3 Lower Hook Fails

IP Rigging Line *4 Lifting Sling Falls

IP Rigging Line \#2 Lower Hook Fails

IP Rigging Line 3 Lower Hook Fails

IP Rigging Line \#4 Lifting Sling Fails

IP Rigging Line \#2 Upper Hook Falls

IP Rigging Line "3 Lower Hook Falls

IP Rigging Line \#4 Lower Hook Falls

IP Rigging Line \#l Lifting siling Fails

IP Rigging Line \#2 Upper Hook Fails

IP Rigging Line \#4 Lifting Sling Fails
B.E.

PROB. PROB.

I. O0E-06

$1.00 E-06$

1. $00 E-06$

1. $00 \mathrm{E}-06$

1. $00 \mathrm{E}-06$

$1.00 E-06$

$1.00 \mathrm{E}-06$

$1.00 \mathrm{E}-06$

1. $00 \mathrm{E}-06$

$1.00 E-06$

1. $00 \mathrm{E}-06$

$1.00 E-06$

$1.00 E-06$

$1.00 \mathrm{E}-06$

$1.00 E-06$

$1.00 \mathrm{E}-06$

1. 00E-06

$1.00 \mathrm{E}-06$

$1.00 E-06$

$1.00 E-06$

$1.00 \mathrm{E}-06$

$1.00 \mathrm{E}-06$

$1.00 E-06$

$1.00 \mathrm{E}-06$

$1.00 \mathrm{E}-06$

1. $00 E-06$

$1.00 E-06$

$1.00 \mathrm{E}-06$

1. $00 \mathrm{E}-06$

$1.00 \mathrm{E}-06$

$1.00 E-06$

1. $00 \mathrm{E}-06$

$1.00 \mathrm{E}-06$

$1.00 E-06$

$1.00 E-06$

1. $00 E-06$

1. $00 \mathrm{E}-06$

$1.00 \mathrm{E}-06$

$1.00 \mathrm{E}-06$

1. $00 \mathrm{E}-06$

$1.00 \mathrm{E}-06$

$1.00 \mathrm{E}-06$

1.00 E-06

$1.00 \mathrm{E}-06$

1. $00 \mathrm{E}-06$

$1.00 E-06$

1.00 E-06

$1.00 E-06$

$1.00 \mathrm{E}-06$

1. 00 E- 06

1. $00 \mathrm{E}-06$
$1.00 \mathrm{E}-06$

$1.00 \mathrm{E}-18$

1.00E-18

$1.00 E-18$

$1.00 E-18$

1.00E-18

1.00E- 18

1. $00 \mathrm{E}-18$

1.00E-18

$1.00 E-18$

1. $00 \mathrm{E}-18$

1.00E- 18

$1.00 E-18$

$1.00 E-18$

$1.00 \mathrm{E}-18$

$1.00 E-18$

$1.00 E-18$

$1.00 E-18$

KWLS2UH

XWLS4S 
CLSDROP.CUT

Filter: 'ALL'

\section{MOOULE/EVENT NAME}

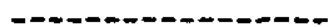

111) KWLS1S

KWLS3S

KWLS45

112) KWLSIUH

KWLS3UH

XWLS4UH

113) KWLSIS

KWLS3UH

KWLS4UH

114) KWLSIS

KWLS3UH

KWLS4S

115) KWLS1LH

KWLS3LH

KWLS4LH

116) KWLSIS

KWLS3S

KWLS4UH

117) KWLSIL.H

KWLS3UH

KWLS4UH

118) KWLSILH

KWLS3S

KWLS4UH

119) KWLSIS

KWLS3UH

KWLS4LH

120) KWLSIUH

KWLS3UH

KWLS4S

121) KWLS1S

KWLS2UH

KWLS4LH

122) KWLS1UH

KWLSZUH

KWLS4LH

123) KWLSIUH

KWLS3S

KWLS4LH

124) KWLS1S

KWLS2UH

KWLS3S

\section{CUTSET REPORT}

Truncation Limit: $1.00 \mathrm{E}-30$

DESCRIPTION

IP Rigging Line \#1 Lifting Sling Fails

IP Rigging Line \#3 Lifting sling Fails

IP Rigging Line $\# 4$ Lifting sling Fails

IP Rigging Line \#l Upper Hook Fails

IP Rigging Line *3 Upper Hook Fails

IP Rigging Line *4 Upper Hook Fails

IP Rigging Line \#l Lifting Sling Fails

IP Rigging Line \#3 Upper Hook Fails

IP Rigging Line \#4 Upper Hook Fails

IP Rigging Line \#l Lifting Sling Fails

IP Rigging Line \#3 Upper Hook Fails

IP Rigging Line \#4 Lifting Sling Fails

IP Rigging Line \#l Lower Hook Fails

IP Rigging Line \#3 Lower Hook Fails

IP Rigging Line \#4 Lower Hook Fails

IP Rigging Line \#l Lifting Sling Fails

IP Rigging Line \#3 Lifting sling Fails

IP Rigging Line \#4 Upper Hook Fails

IP Rigging Line \#I Lower Hook Fails

IP Rigging Line $\# 3$ Upper Hook Fails

IP Rigging Line *4 Upper Hook Fails

IP Rigging Line \#l Lower Hook Fails

IP Rigging Line \#3 Lifting sling Fails

IP Rigging Line \#4 Upper Hook Fails

IP Rigging Line \#l Lifting Sling Fails

IP Rigging Line \#3 Upper Hook Fails

IP Rigging Line *4 Lower Hook Fails

IP Rigging Line \#1 Upper Hook Fails

IP Rigging Line \#3 Upper Hook Fails

IP Rigging Line \#4 Lifting Sling Fails

IP Rigging Line \#1 Lifting sling Fails

IP Rigging Line \#2 Upper Hook Fails

IP Rigging Line \#4 Lower Hook Fails

IP Rigging Line \#1 Upper Hook Fails

IP Rigging Line \#2 Upper Hook Fails

IP Rigging Line *4 Lower Hook Fails

IP Rigging Line \#1 Upper Hook Fails

IP Rigging Line \#3 Lifting Sling Fails

IP Rigging Line \#4 Lower Hook Fails

IP Rigging Line \#l Lifting Sling Fatls

IP Rigging Line \#2 Upper Hook Fails

IP Rigging Line \#3 Lifting Si ing Fails
B.E.

PROB.

-...-

1. $00 \mathrm{E}-06$

$1.00 \mathrm{E}-06$

1. 00 E-06

$1.00 \mathrm{E}-06$

1. $00 \mathrm{E}-06$

1.00 E-06

1. $00 \mathrm{E}-06$

1. $00 \mathrm{E}-06$

1.00E-06

1. $00 \mathrm{E}-06$

1. $00 \mathrm{E}-06$

1. $00 \mathrm{E}-06$

1. $00 \mathrm{E}-06$

1. $00 \mathrm{E}-06$

1. $00 \mathrm{E}-06$

1. $00 \mathrm{E}-06$

1. 00 E-06

$1.00 \mathrm{E}-06$

$1.00 E-06$

1. $00 \mathrm{E}-06$

1. 00 E-06

1. $00 \mathrm{E}-06$

1.00E-06

1. $00 \mathrm{E}-06$

1. $00 \mathrm{E}-06$

$1.00 \mathrm{E}-06$

$1.00 \mathrm{E}-06$

1. $00 \mathrm{E}-06$

$1.00 \mathrm{E}-06$

$1.00 \mathrm{E}-06$

1. $00 \mathrm{E}-06$

1. $00 \mathrm{E}-06$

$1.00 \mathrm{E}-06$

$1.00 \mathrm{E}-06$

1. $00 \mathrm{E}-06$

1. $00 \mathrm{E}-06$

$1.00 E-06$

$1.00 E-06$

1. $00 \mathrm{E}-06$

1. $00 \mathrm{E}-06$

$1.00 \mathrm{E}-06$

$1.00 \mathrm{E}-06$
Page 7

MOD./CS.

PROB.

-...-....

$1.00 E-18$

$1.00 E-18$

$1.00 E-18$

$1.00 E-18$

1. $00 \mathrm{E}-18$

$1.00 E-18$

$1.00 \mathrm{E}-18$

$1.00 E-18$

$1.00 E-18$

$1.00 \mathrm{E}-18$

$1.00 E-18$

$1.00 E-18$

1.00E-18

$1.00 E-18$ 
PEER REVIEW CHECKLIST

Document Title: $\quad$ SNF-5413, Probability of Potential MCO Cask Drop in the K-West Basin South Loadout Pit

Document Author: Tom Powers

Document Date: December 1999

Scope of Review:

Yes No NA/

[] [] [Y

[4 [] []

[i) [] []

[4 [] []

4) [1] []

[4 [] []

lat [] []

LY [] []

$\left[\begin{array}{lll}4 & {[}\end{array}\right][]$

U [] []

[4 [] []

H [] []

[] [] [b

[] [] [Q

[] [] [4

[] [] [

[] [] H

[] $Y$ []

Previous reviews complete and cover analysis, up to scope of this review, with no gaps.

Problem completely defined.

Accident scenarios developed in a clear and logical manner.

Necessary assumptions explicitly stated and supported.

Computer codes and data files documented.

Data used in calculations explicitly stated in document.

Data checked for consistency with original source information as applicable. Mathematical derivations checked including dimensional consistency of results.

Models appropriate and used within range of validity or use outside range of established validity justified.

Hand calculations checked for errors. Spreadsheet results should be treated exactly the same as hand calculations.

Software input correct and consistent with document reviewed.

Software output consistent with input and with results reported in document reviewed.

Limits/criteria/guidelines applied to analysis results are appropriate and referenced. Limits/criteria/guidelines checked against references.

Safety margins consistent with good engineering practices.

Conclusions consistent with analytical results and applicable limits.

Results and conclusions address all points required in the problem statement.

Format consistent with appropriate NRC Regulatory Guide or other standards

Review calculations, comments, and/or notes are attached.

\section{И [I [] Document approved.}

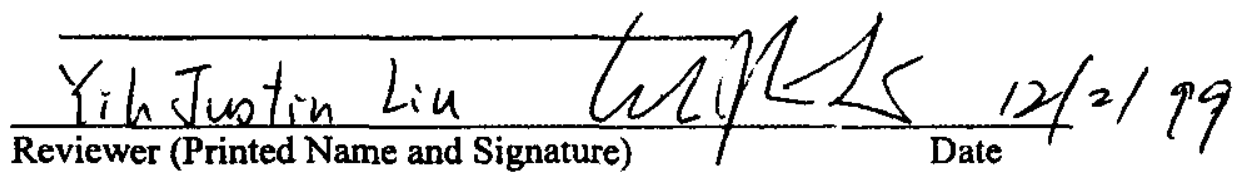


SNF-5413 REV 0

This page intentionally left blank. 


\section{DISTRIBUTION SHEET}

\begin{tabular}{|c|c|c|c|c|c|}
\hline \multirow{2}{*}{$\begin{array}{l}\text { To } \\
\text { Distribution }\end{array}$} & \multirow{2}{*}{\multicolumn{3}{|c|}{$\begin{array}{l}\text { From } \\
\text { T. B. Powers, Nuclear Safety }\end{array}$}} & \multicolumn{2}{|l|}{ Page 1 of 1} \\
\hline & & & & \multicolumn{2}{|c|}{ Date $12 / 06 / 99$} \\
\hline \multicolumn{4}{|l|}{ Project Title/Work Order } & \multicolumn{2}{|c|}{ EDT No. 626899} \\
\hline \multicolumn{4}{|l|}{ SNF-5413, Rev. 0} & \multirow{2}{*}{\multicolumn{2}{|c|}{ ECN No. N/A }} \\
\hline \multicolumn{4}{|c|}{$\begin{array}{l}\text { Potential Multi-Canister Overpack Cask Drop in the K West Basin South } \\
\text { Loadout Pit }\end{array}$} & & \\
\hline Name & MSIN & $\begin{array}{c}\text { Text } \\
\text { With All } \\
\text { Attach. }\end{array}$ & Text Only & $\begin{array}{c}\text { Attach./ } \\
\text { Appendix } \\
\text { Only }\end{array}$ & $\begin{array}{l}\text { EDT/ECN } \\
\text { Only }\end{array}$ \\
\hline C. J. Alderman & R3-11 & $\mathbf{X}$ & & & \\
\hline K. E. Ard & $\mathrm{X} 3-85$ & $\mathbf{X}$ & & & \\
\hline R. L. Boyleston & R3-26 & $X$ & & & \\
\hline J. R. Ellis (5) & R3-26 & $\mathbf{X}$ & & & \\
\hline R. L. Garrett & R3-26 & $\mathbf{X}$ & & & \\
\hline K. D. Gibson & R3-26 & $X$ & & & \\
\hline B. S. Lew & X3-79 & $X$ & & & \\
\hline T. B. Powers & R3-26 & $\mathbf{X}$ & & & \\
\hline J. L. Weamer & X3-85 & $\mathbf{X}$ & & & \\
\hline R. H. Webb & R3-26 & $X$ & & & \\
\hline SNF Project Files & R3-11 & $\mathrm{X}$ & & & \\
\hline Central Files & B1-07 & $\mathrm{X}$ & & & \\
\hline
\end{tabular}

